\title{
The complete genome sequence of the algal symbiont Dinoroseobacter shibae: a hitchhiker's guide to life in the sea
}

Irene Wagner-Döbler ${ }^{1}$, Britta Ballhausen ${ }^{1}$, Martine Berger ${ }^{2}$, Thorsten Brinkhoff ${ }^{2}$, Ina Buchholz ${ }^{1}$, Boyke Bunk ${ }^{3}$, Heribert Cypionka ${ }^{2}$, Rolf Daniel ${ }^{4}$, Thomas Drepper ${ }^{5}$, Gunnar Gerdts ${ }^{6}$, Sarah Hahnke ${ }^{2}$, Cliff Han ${ }^{7}$, Dieter Jahn ${ }^{3}$, Daniela Kalhoefer ${ }^{2}$, Hajnalka Kiss ${ }^{7}$, Hans-Peter Klenk ${ }^{8}$, Nikos Kyrpides ${ }^{7}$, Wolfgang Liebl ${ }^{9}$, Heiko Liesegang ${ }^{4}$, Linda Meincke ${ }^{7}$, Amrita Pati $^{7}$, Jörn Petersen ${ }^{8}$, Tanja Piekarski ${ }^{3}$, Claudia Pommerenke ${ }^{1}$, Silke Pradella ${ }^{8}$, Rüdiger Pukall ${ }^{8}$, Ralf Rabus ${ }^{2}$, Erko Stackebrandt ${ }^{8}$, Sebastian Thole ${ }^{2}$, Linda Thompson ${ }^{7}$, Petra Tielen ${ }^{3}$, Jürgen Tomasch ${ }^{1}$, Mathias von Jan ${ }^{8}$, Nittaya Wanphrut ${ }^{3}$, Antje Wichels ${ }^{6}$, Hajo Zech ${ }^{2}$ and Meinhard Simon ${ }^{2}$

${ }^{1}$ Helmholtz-Centre for Infection Research, Braunschweig, Germany; ${ }^{2}$ Institute for Chemistry and Biology of the Marine Environment, University of Oldenburg, Oldenburg, Germany; ${ }^{3}$ Institute of Microbiology, Technical University of Braunschweig, Braunschweig, Germany; ${ }^{4}$ Institute for Microbiology and Genetics, University of Göttingen, Göttingen, Germany; ${ }^{5}$ Forschungszentrum Jülich, Jülich, Germany; ${ }^{6}$ Biologische Anstalt Helgoland, Alfred-Wegener Institute for Polar and Marine Research, Bremerhaven, Germany; ${ }^{7}$ Joint Genome Institute, San Francisco, CA, USA; ${ }^{8}$ German Collection for Microorganisms and Cell Cultures, Braunschweig, Germany and ${ }^{9}$ Technical University of München, München, Germany

\begin{abstract}
Dinoroseobacter shibae DFL12 ${ }^{\top}$, a member of the globally important marine Roseobacter clade, comprises symbionts of cosmopolitan marine microalgae, including toxic dinoflagellates. Its annotated 4417868 bp genome sequence revealed a possible advantage of this symbiosis for the algal host. $D$. shibae DFL12 ${ }^{\top}$ is able to synthesize the vitamins $B_{1}$ and $B_{12}$ for which its host is auxotrophic. Two pathways for the de novo synthesis of vitamin $B_{12}$ are present, one requiring oxygen and the other an oxygen-independent pathway. The de novo synthesis of vitamin $B_{12}$ was confirmed to be functional, and $D$. shibae $D F L 12^{\top}$ was shown to provide the growth-limiting vitamins $B_{1}$ and $B_{12}$ to its dinoflagellate host. The Roseobacter clade has been considered to comprise obligate aerobic bacteria. However, $D$. shibae $\mathrm{DFL12}^{\mathrm{T}}$ is able to grow anaerobically using the alternative electron acceptors nitrate and dimethylsulfoxide; it has the arginine deiminase survival fermentation pathway and a complex oxygen-dependent Fnr (fumarate and nitrate reduction) regulon. Many of these traits are shared with other members of the Roseobacter clade. D. shibae DFL12 ${ }^{\top}$ has five plasmids, showing examples for vertical recruitment of chromosomal genes (thiC) and horizontal gene transfer (cox genes, gene cluster of $47 \mathrm{~kb}$ ) possibly by conjugation (vir gene cluster). The long-range ( $80 \%)$ synteny between two sister plasmids provides insights into the emergence of novel plasmids. $D$. shibae DFL12 ${ }^{\top}$ shows the most complex viral defense system of all Rhodobacterales sequenced to date.

The ISME Journal (2010) 4, 61-77; doi:10.1038/ismej.2009.94; published online 10 September 2009

Subject Category: integrated genomics and post-genomics approaches in microbial ecology

Keywords: symbiosis; vitamin; cobalamin; thiamine; Roseobacter, dinoflagellate
\end{abstract}

\section{Introduction}

One of the most abundant and metabolically versatile groups of bacteria in the world's oceans is

Correspondence: I Wagner-Döbler, Helmholtz-Centre for Infection Research, Inhoffenstr. 7, Braunschweig, Germany.

E-mail: iwd@helmholtz-hzi.de

Received 27 April 2009; revised 29 June 2009; accepted 14 July 2009; published online 10 September 2009 the Roseobacter clade. Members of this alphaproteobacterial lineage are prominently involved in the global marine carbon and sulfur cycles (Moran et al., 2004; Selje et al., 2004; Buchan et al., 2005; WagnerDobler and Biebl, 2006; Howard et al., 2006; Moran and Miller, 2007; Brinkhoff et al., 2008). Many Roseobacter species live as epibionts on marine algae where they reach high abundance during phytoplankton blooms (reviewed by Buchan et al. (2005)). Some phytoplankton blooms, the so-called 
red tides, are caused by toxic dinoflagellates, and Roseobacter species were frequently isolated from their laboratory cultures (Lafay et al., 1995; Prokic et al., 1998; Miller and Belas, 2004), and also detected on dinoflagellates in nature (Hasegawa et al., 2007). A direct interaction between these algae and their associated bacteria is suggested by the fact that Roseobacter cells have been found attached to the surface of toxic Pfiesteria species using fluorescent in situ hybridization (FISH) (Alavi et al., 2001).

The Roseobacter isolates from dinoflagellate cultures must be able to grow on metabolites excreted by the algae because they are heterotrophs (Moran and Miller, 2007) and there are no carbon sources present in the mineral media used for cultivating phototrophic algae. Many Roseobacter bacteria can degrade dimethylsulfoniopropionate (Moran et al., 2007), an osmoprotectant released in large quantities during algal blooms, and they show positive chemotaxis toward this compound (Yoch 2002; Miller et al., 2004; Miller and Belas, 2006). A strain of the abundant RCA (Roseobacter clade-affiliated) cluster could be cultivated in coculture with an axenic dinoflagellate (Mayali et al., 2008). These studies show that Roseobacter bacteria can thrive on algal metabolites. However, it is presently not known whether this relationship provides an advantage to the dinoflagellate host.

In this study, we report the complete genome sequence of Dinoroseobacter shibae DFL12 ${ }^{\mathrm{T}}$, the type strain of a species from the Roseobacter clade. It was isolated from Prorocentrum lima, a benthic dinoflagellate, by picking a single dinoflagellate cell from a culture, washing it several times and placing it on an agar surface (Allgaier et al., 2003; Biebl et al., 2005). P. lima produces okadaic acid, which can cause diarrhetic shellfish poisoning during red tides (Pan et al., 1999). D. shibae DFL12 ${ }^{\mathrm{T}}$ was chosen for sequencing because of its symbiosis with dinoflagellates, its ability to perform light-driven ATP synthesis using bacteriochlorophyll $a$ in the presence of oxygen (Allgaier et al., 2003; Biebl and Wagner-Dobler, 2006; Wagner-Dobler and Biebl, 2006), the large number of extrachromosomal replicons (Pradella et al., 2004) and its novel acylated homoserine lactone (AHL) compounds (WagnerDobler et al., 2005). The complete genome sequence of $D$. shibae DFL $12^{\mathrm{T}}$ revealed traits that presumably are highly adaptive in the habitat of bloom-forming algae and that may be characteristic for the whole Roseobacter clade. Moreover, we discovered an essential gift provided to the dinoflagellate by the bacteria.

\section{Materials and methods}

Sequencing, assembly and finishing The genome of $D$. shibae DFL $12^{\mathrm{T}}$ was sequenced at the Joint Genome Institute (JGI) Production Geno- mics Facility using a combination of 3 and $8 \mathrm{~kb}$ (plasmid), and $40 \mathrm{~kb}$ (fosmid) DNA libraries. All general aspects of library construction and sequencing performed at the JGI can be found at http:// www.jgi.doe.gov. The Phred/Phrap/Consed software package (http://www.phrap.com) was used for sequence assembly and quality assessment (Ewing and Green, 1998; Ewing et al., 1998; Gordon et al., 1998). After the shotgun stage, reads were assembled with parallel phrap (High Performance Software, LLC). Mis-assemblies were corrected with Dupfinisher (Han and Chain, 2006) or transposon bombing of bridging clones (Epicentre Biotechnologies, Madison, WI, USA). Gaps between contigs were closed by editing in Consed, custom primer walk or PCR amplification. A total of 742 additional reactions were necessary to close the gaps and to raise the quality of the finished sequence. The completed genome sequences of $D$. shibae DFL12 ${ }^{\mathrm{T}}$ contain 67596 reads, achieving an average of a 11-fold sequence coverage per base with an error rate less than 1 in 100000 . The sequences of D. shibae DFL12 ${ }^{\mathrm{T}}$, comprising a chromosome and five plasmids, can be accessed using the GenBank accession numbers NC_009952，NC_009955，NC_009956，NC_009957, NC_009958 and NC_009959. Manual curation and reannotation of the genome was carried out using The Integrated Microbial Genomes Expert Review System (img/er http://imgweb.jgi-psf.org) (Markowitz et al., 2008) and the Artemis software package (http:// www.sanger.ac.uk/Software/Artemis/v9).

\section{Phylogenetic analysis}

Phylogenetic analyses of $16 \mathrm{~S}$ rRNA gene sequences were performed with the ARB software package (http://www.arb-home.de) (Ludwig et al., 2004). A phylogenetic tree was constructed using neighborjoining and maximum-likelihood analyses. Only sequences with more than $1200 \mathrm{bp}$ were considered in these calculations. Sequences $<1200 \mathrm{bp}$ were added afterward using parsimony.

\section{Design of D. shibae-specific oligonucleotides for PCR and FISH}

Specific primers and probes were developed using the ProbeDesign function of the ARB software package (http://www.arb-home.de). Sequences of specific primers are DSH176f (5'-CGTATGTGGCC TTCGGGC-3') and DSH1007r (5'-GCTTCCGTCTCC GGAAGCC-3'). Specificity of primer sequences was checked with the NCBI and RDP databases (http:// www.ncbi.nlm.nih.gov and http://rdp.cme.msu. edu/) and resulted in at least one mismatch to 16S rRNA gene sequences of non-target organisms. Probe DSH176-HRP (5'-GCCCGAAGGCCACATACG-3') was used for FISH, in combination with helper probes DSH176-H1 (5'-GTATTACTCCCAGTTTCC CA- $\left.3^{\prime}\right)$ and DSH176-H2 (5'-ATCCTTTGGCGATAAA TCTTTC- $3^{\prime}$ ). 
Sample preparation for CARD-FISH

In total, $5 \mathrm{ml}$ of the Prorocentrum culture were fixed with $5 \mathrm{ml}$ paraformaldehyde $(4 \% \mathrm{w} / \mathrm{v})$ for $1 \mathrm{~h}$ and filtered onto a $0.2-\mu \mathrm{m}$ filter (Nucleopore Track Etch PC MB $25 \mathrm{~mm}$, Whatman Nr. 1110656, Whatman plc, Maidstone, Kent, UK) or a $10-\mu \mathrm{m}$ filter (Polycarbonate Membrane Filters, TCTP04700, Millipore Corporation, Billerica, MA, USA). Cells were washed eight times with distilled water. Reference strains D. shibae DFL $12^{\mathrm{T}}$ (0 mismatches to probe DSH176) and Sulfitobacter guttiformis DSM11458 ${ }^{\mathrm{T}}$ (two mismatches to probe DSH176) were filtered onto $0.2-\mu \mathrm{m}$ polycarbonate filters and fixed with paraformaldehyde $(2 \% \mathrm{w} / \mathrm{v})$ for $1 \mathrm{~h}$, rinsed with $1 \mathrm{ml}$ $1 \times$ phosphate buffer solution and subsequently with $1 \mathrm{ml}$ distilled water. Filters were air dried and stored at $-20^{\circ} \mathrm{C}$ until further processing.

\section{CARD-FISH}

CARD-FISH (Catalyzed reporter deposition FISH) was performed according to Sekar et al. (2003). Hybridization conditions were as follows: $2 \mathrm{~h}$ of hybridization at $35{ }^{\circ} \mathrm{C}(60 \%$ formamide $), 30 \mathrm{~min}$ washing at $37^{\circ} \mathrm{C}(14 \mathrm{mM} \mathrm{NaCl})$ and $30 \mathrm{~min}$ amplification at $37^{\circ} \mathrm{C}$. Per $400 \mu \mathrm{l}$ hybridization buffer, $15 \mu \mathrm{l}$ of the HRP (horseradish peroxidase) probe DSH176HRP and $15 \mu \mathrm{l}$ of each unlabeled helper oligonucleotide (DSH176-H1 and DSH176-H2) were used (probe solutions $50 \mathrm{ng} \mathrm{\mu l}^{-1}$ ): Tyramine-HCl was labeled with fluorescein-5-isothiocyanate as described by Pernthaler et al. (2002). To avoid unspecific accumulation of dye in the cells, the last washing step in phosphate buffer solution $(1 \times)$ amended with TritonX-100 (0.05\%) was extended to $30 \mathrm{~min}$. Counterstaining was performed with Vectashieldmounting medium with 4',6-Diamidino-2-phenylindole $\left(1.5 \mu \mathrm{g} \mathrm{ml}^{-1}\right.$; Vector Laboratories, Peterborough, England).

\section{Comparative genomics}

The Integrated Microbial Genomes Expert Review System (img/er http://imgweb.jgi-psf.org (Markowitz et al., 2008) was used for comparative analysis on the basis of the nine presently available completely sequenced genomes of the Rhodobacterales: Jannaschia sp. CCS1 (Moran et al., 2007), Roseobacter denitrificans (Swingley et al., 2007), Silicibacter pomeroyi (Moran et al., 2004), Silicibacter sp. TM1040 (Moran et al., 2007), three strains of Rh. sphaeroides (Choudhary et al., 2007) as well as Paracoccus denitrificans (JGI Institute, unpublished).

\section{CRISPR}

Homologs of cas genes were detected using tools of the BLAST package (Altschul et al., 1990). CRISPR arrays were detected by the CRISPR recognition tool (Bland et al., 2007). Comparative analysis of repeat sequences was done both manually and by CRISPRdb (Grissa et al., 2007). The origin of spacer sequences was searched for in the CAMERA databases (Seshadri et al., 2007) (http://camera. calit2.net).

Regarding the methods for dinoflagellate cultivation and sampling, isolation of genomic DNA, PCR, cloning and sequencing, determination of vitamin $\mathrm{B}_{12}$ and coculture experiments, see Supplementary material 10.

\section{Results and discussion}

Ecological niche and phylogeny

D. shibae DFL $12^{\mathrm{T}}$ was isolated from P. lima (Biebl et al., 2005). This phototrophic dinoflagellate occurs in sand and sediment and to some extent also in the water column, but reaches its highest densities in biofilms on marine macroalgae, macrophytes, corals, mussels and oysters (Levasseur et al., 2003; Vershinin et al., 2005; Okolodkov et al., 2007; Parsons and Preskitt, 2007).

Several closely related strains were isolated from the dinoflagellate Alexandrium ostenfeldii (Allgaier et al., 2003). Using PCR with D. shibae-specific primers for the $16 \mathrm{~S}$ rRNA gene and sequencing of the obtained bands for confirmation, D. shibae was also detected in cultures of Protoceratium reticulatum, a dinoflagellate isolated from the North Sea. All three host species are cosmopolitan, toxic algae causing diarrhetic shellfish poisoning (Aasen et al., 2005). Finally, D. shibae was isolated from Isochrysis galbana, a member of the class Haptophyceae (Genbank accession EF512132). This nontoxic alga is cultivated as food for bivalves in aquaculture. Thus, D. shibae is not restricted to toxic dinoflagellates, but is associated with a variety of cosmopolitan marine microalgae. Figure 1 shows the phylogenetic position of all currently known D. shibae strains within the Roseobacter clade and indicates from which algae they were isolated. The similarity of these sequences to $D$. shibae $\mathrm{DFL} 12^{\mathrm{T}}$ is between $97.2 \%$ and $99.8 \%$, indicating that they probably belong to the same species, but additional data are needed (Rossello-Mora and Amann, 2001; Stackebrandt et al., 2002; Gevers et al., 2005).

A physical association between host algae and bacteria is suggested by the fact that $D$. shibae DFL $12^{\mathrm{T}}$ was isolated from single washed cells of the dinoflagellate (Biebl et al., 2005). Moreover, it can be seen attached to $P$. lima in coculture (Figure 2). In this study, dinoflagellates were separated from suspended bacteria using $10-\mu \mathrm{m}$ polycarbonate filters, washed eight times and stained using CARD-FISH with probes specific for $D$. shibae DFL12 ${ }^{\mathrm{T}}$. Many bacteria can be seen adhering to the surface of the dinoflagellate, and some are freely suspended in the medium. It remains to be seen if a genetic program coordinates the switch between planktonic growth and growth as an epibiont in D. shibae. 


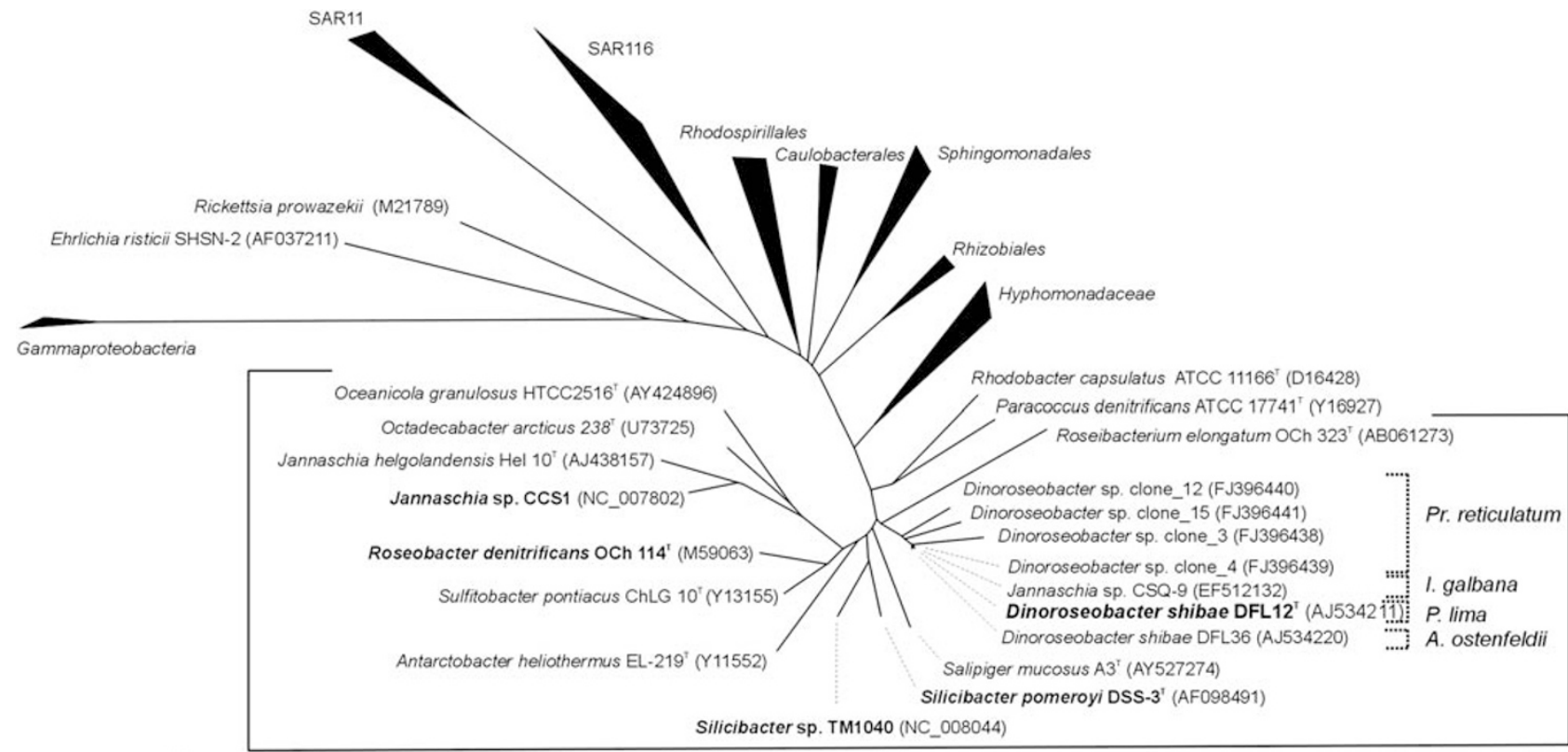

0.1

\section{Roseobacter clade}

Figure 1 Phylogenetic position of Dinoroseobacter shibae DFL12 ${ }^{\mathrm{T}}$ and closely related strains and phylotypes within the Rhodobacteraceae (Alphaproteobacteria) based on 16S rRNA gene comparisons. All names written in boldface indicate organisms whose complete genome sequences have already been determined. The phylogenetic tree was generated using the maximum-likelihood method. Selected members of the Gammaproteobacteria were used as an outgroup (not shown). The eukaryotic host algae from which the strains were isolated are indicated next to the dotted brackets. Pr., Protoceratium (Dinophyceae); I., Isochrysis (Haptophyceae); P., Prorocentrum (Dinophyceae); A., Alexandrium (Dinophyceae). Bar $=0.1$ substitutions per nucleotide position.
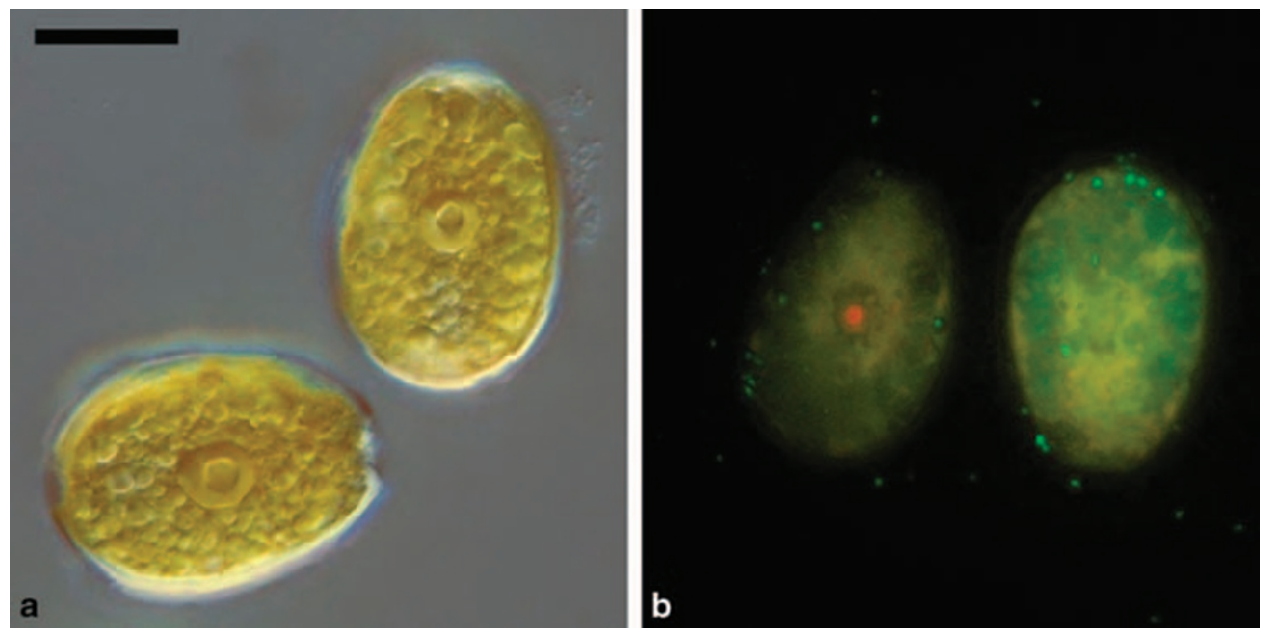

Figure 2 Specific attachment of $D$. shibae DFL $12^{\mathrm{T}}$ to its dinoflagellate host Prorocentrum lima. (a) Differential interference contrast (DIC) image of dinoflagellates from a non-axenic culture to which cells of strain DFL $12^{\mathrm{T}}$ had been added 2 months before; (b) Catalyzed reporter deposition fluorescent in situ hybridization (CARD-FISH) with Dinoroseobacter-specific 16S rRNA probes showing most cells of D. shibae DFL12 ${ }^{\mathrm{T}}$ (green dots) closely attached to the dinoflagellate. Combined images generated by means of PICOLAY (http:// www.picolay.de) from a series of six pictures taken at sequential focus levels. Bar $=20 \mu \mathrm{m}$. The central round structure in the cell center seen in (a) is the pyrenoid, a specialized area of the plastid that contains high levels of Rubisco. It is typically surrounded by a starch sheath that can also be seen. The crystal-like ultrastructure of the pyrenoid (Kowalik, 1969) may be the reason for its orange appearance in the left cell in (b).

\section{General characteristics of the genome}

The D. shibae type strain DFL12 ${ }^{\mathrm{T}} \quad$ (=DSM $16493^{\mathrm{T}}=$ NCIMB $14021^{\mathrm{T}}$ ) has a genome size of $4417 \mathrm{kbp}$, similar to the other fully sequenced Roseobacter genomes (Supplementary material S1). The genome contains 4198 protein-encoding genes.
About $28 \%$ of the derived gene products have no predicted function. The finished genome sequence indicates a circular conformation of the chromosome and the five plasmids (Figure 3). Previously the presence of plasmids with linear conformation was hypothesized for two D. shibae strains and 


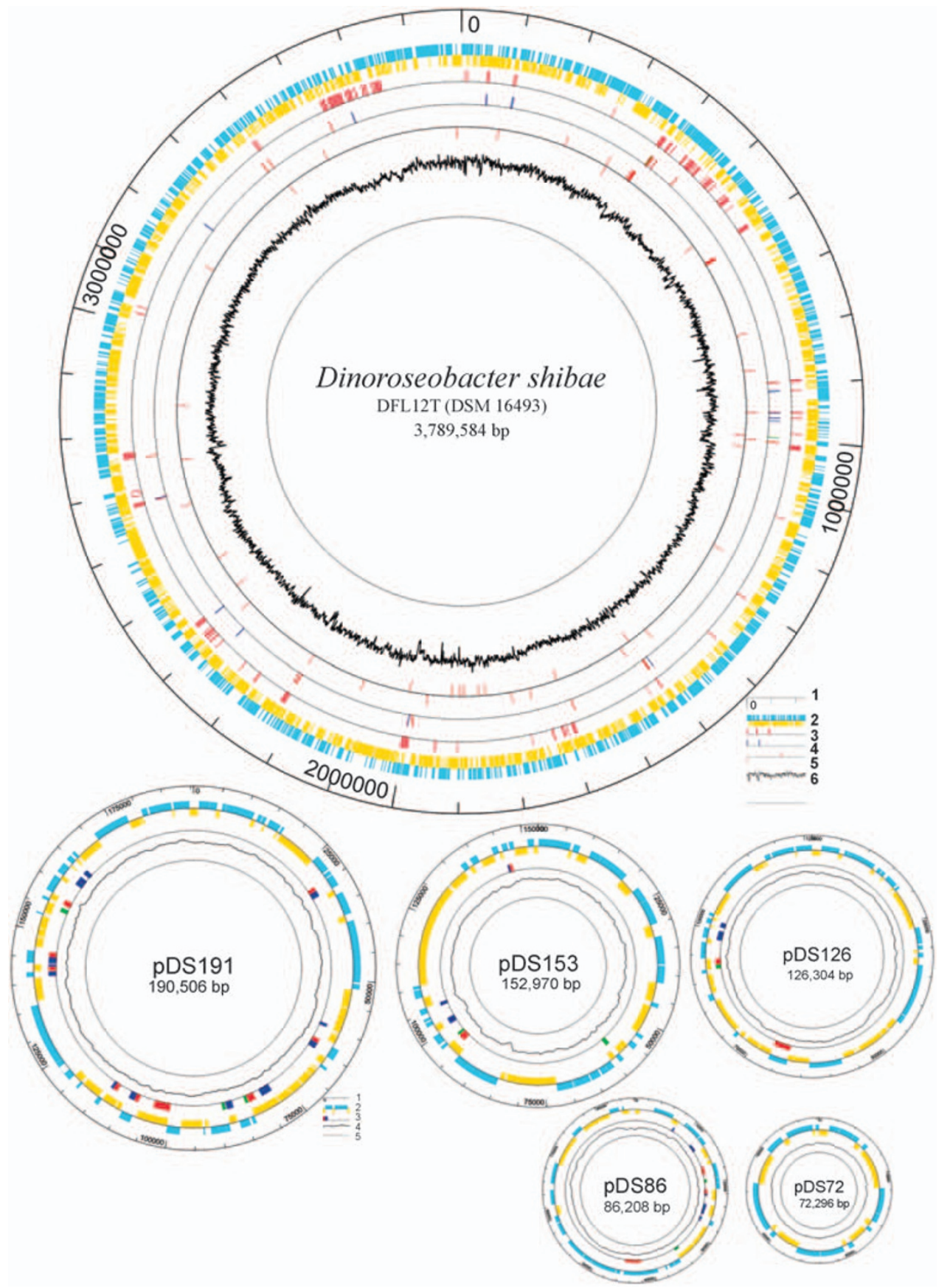

Figure 3 Circular representation of the chromosome and plasmids of D. shibae DFL12 ${ }^{\mathrm{T}}$. The ring of the chromosome depicts (starting with the outer ring) (1) the scale in basepairs; (2) all protein-encoding genes, clockwise-transcribed genes in blue and counterclockwisetranscribed genes in yellow; (3) alien genes, that is, genes that are likely acquired by horizontal gene transfer; (4) genes related to DNA flexibility: transposases (blue), integrases (red) and recombinases (green); (5) rRNA and tRNA genes; (6) the GC content. The rings of the plasmids depict (1) the scale in base pairs; (2) all protein-encoding genes; (3) genes related to DNA flexibility; (4) rRNA and tRNA genes and (5) the GC content. Alien genes are not shown in the plasmids, because these contigs are too small for their calculation.

several related species (Pradella et al., 2004). We investigated the plasmid structure in $D$. shibae DFL12 by a restriction assay combined with length separation through pulsed-field gel electrophoresis and could confirm the circular conformation (Supplementary material S2). This is in agreement with the absence of genes typically associated with linear plasmids, for example, the telomere resolvase (Meinhardt et al., 1997; Kobryn and Chaconas, 2001).

\section{Comparative genomics}

D. shibae $\mathrm{DFL}^{\mathrm{T}}{ }^{\mathrm{T}}$ harbors all biogeochemically important traits reported previously from fully 
sequenced Roseobacter isolates, namely anaerobic anoxygenic photosynthesis (pufLM genes), carbon monoxide oxidation (cox genes), aromatic compound degradation ( $p c a G H$ and boxC genes), sulfur oxidation $(\operatorname{sox} B)$, denitrification (nirS/K), nitrate assimilation (nasA), phosphonate use ( $p h n$ ), type IV secretion (vir genes) and dimethylsulfoniopropionate degradation $(d m d A)$ (Supplementary material S3). Several families of transposases/integrases (61 and 43 copies, respectively) and site-specific recombinases/resolvases (11 copies) belong not only to the largest gene families, but also they are more frequent than in other members of the Roseobacter clade, indicating a large potential for DNA exchange in D. shibae DFL12 ${ }^{\mathrm{T}}$. Proteins involved in information processing usually represent the role categories showing the least variation between closely related organisms. Their comparative analysis is described in Supplementary material S1.

\section{The central energy metabolism and its regulation}

\section{Central carbon metabolism}

The central carbon metabolism is reconstructed in Supplementary material S4. Glucose breakdown is potentially possible through glycolysis (EmbdenMeyerhoff-Parnas pathway) and the Entner-Doudoroff pathway, the latter being closely connected to the oxidative pentose phosphate pathway. Interestingly, a fluxom analysis using ${ }^{13} \mathrm{C}$ labeling techniques showed that glucose breakdown is carried out exclusively using the Entner-Doudoroff pathway; thus, the alternative routes are used only for anabolic purposes (Fürch et al., 2009). The Calvin cycle is lacking, indicated by the absence of the key enzyme Rubisco, as in all Roseobacter strains (Swingley et al., 2007). Carbon dioxide might be fixed by anapleurotic enzymes either through (1) a two-step reaction involving pyruvate-orthophosphate dikinase and phosphoenolpyruvate carboxylase or through (2) pyruvate carboxylase. Genes for both carboxylases are present in all fully sequenced Roseobacter strains. Pyruvate carboxylase requires biotin as a cofactor, and hence the need to supply D. shibae DFL12 ${ }^{\mathrm{T}}$ with this vitamin when it is grown on minimal medium (Biebl et al., 2005). A fluxom analysis revealed that, indeed, this enzyme displays the major $\mathrm{CO}_{2}$-assimilating route in $D$. shibae (Fürch et al., 2009). D. shibae DFL $12^{\mathrm{T}}$ is the only fully sequenced Roseobacter strain harboring the arginine deiminase pathway, which allows one to carry out a survival fermentation process known from the Bacillus and Pseudomonas species (Eschbach et al., 2004; Williams et al., 2007).

\section{Electron transport chains}

Complex electron transport systems were found (Supplementary material S5), including seven electron-donating primary dehydrogenases, such as for
L- and D-lactate, glycerol-3-phosphate, NADH and succinate, and respiratory dehydrogenases for glucose and gluconate. The presence of the aerobically performed anoxygenic photosynthesis further complicates the electron transport machinery. Just as in the mitochondria, which are derived from Alphaproteobacteria, a cytochrome $b c_{1}$ complex is available. Electron flux can occur from ubiquinol, the reduced form of ubichinone, through the $b c_{1}$ complex and different cytochrome c molecules to two types of cytochrome c oxidases to reduce molecular oxygen to water. Consequently, a close coordination between light-dependent cyclic electron transport (photosynthesis) and respiration is required, the mechanism of which remains to be elucidated.

A complete denitrification pathway and a dimethylsulfoxide (DMSO) reductase are available for the reduction of the alternative electron acceptors DMSO and nitrate. Interestingly, the organism uses the Nap (periplasmic) type nitrate reductase, which is oriented toward the periplasmic space and is active both under aerobic and anaerobic conditions, instead of the Nar (respiratory) type facing the cytoplasm, and is induced only under anaerobic/ microaerophilic conditions. Anaerobic growth using nitrate as an electron acceptor was confirmed experimentally in a defined mineral medium (data not shown).

\section{Oxygen-dependent regulation of the central energy metabolism}

We deduced the regulon for the global oxygendependent transcriptional regulator for fumarate and nitrate reduction, Fnr (Supplementary material S3). Six Fnr/Crp (cAMP receptor protein) type regulators are encoded by the genome of $D$. shibae DFL $12^{\mathrm{T}}$. However, only one of the deduced proteins carries the cysteine residues required for iron sulfur cluster formation. Two others resemble Fnr-type regulators such as Dnr and DnrD (transcription factor for denitrification gene expression). Interestingly, Dnr is located directly upstream of the nos operon encoding a nitrous oxide reductase, the enzyme catalyzing the transformation of $\mathrm{N}_{2} \mathrm{O}$ to $\mathrm{N}_{2}$, the last step of denitrification. Such a gene arrangement has not been found before in denitrifying bacteria, for example, in $R$. denitrificans.

Using a position weight matrix approach (Munch et al., 2005), the genome was searched for potential Fnr-binding sites. In agreement with findings for other Gram-negative bacteria, the promoter region of genes for high-affinity oxygen-dependent cytochrome c oxidases ( $\mathrm{cbb}_{3}$-type), alternative anaerobic systems including the NADH dehydrogenase, the quinone oxidoreductase and the corresponding cofactor biosynthesis genes (hemN1, hemN2, hemA and moaC) are all carrying Fnr-binding sites. No obvious Fnr boxes were found upstream of the various operons involved in denitrification and DMSO reduction. Interestingly, three universal 
stress protein-like genes and eight potential regulator genes are also carrying Fnr boxes. Two of these regulators are suppressor proteins of the heat shock chaperone DnaK (DksA), and the function of the other six regulators is unknown. The Fnr box is also present in promoters of bacteriochlorophyll biosynthesis genes, but it is not possible to predict whether Fnr induces or represses the expression of the corresponding genes.

The Fnr regulator is not a unique feature of D. shibae DFL12 ${ }^{\mathrm{T}}$. Searching the complete genome sequences of the Roseobacter clade with the D. shibae Fnr by reciprocal best hit BLAST showed that one copy is present in all of them. Thus, the ability to fine-tune their metabolism to anoxic conditions is a general trait of the Roseobacter clade.

Nutrients provided by the algal host and their uptake The pathways for the known growth substrates of D. shibae DFL12 ${ }^{\mathrm{T}}$ (Biebl et al., 2005) could be reconstructed from the genome sequence. Interestingly, most of them are Krebs cycle intermediates (fumarate, succinate, pyruvate and citrate). They may be released from the algal host after cell death or during photosynthesis. Photosynthate release from phytoplankton can be up to $40 \%$ of primary production (Wang and Douglas, 1997) and forms the basis of the microbial loop (Azam et al., 1983). D. shibae DFL12 ${ }^{\mathrm{T}}$ also uses acetate and glucose, important components of the marine dissolved organic carbon (Aluwihare et al., 2002; Biersmith and Benner, 1998). Growth also occurs on fructose and glyceraldehyde-3-phosphate, products of the photosynthetic Calvin-Benson cycle. The dimethylsulfoniopropionate breakdown product DMSO can be used as an alternative electron acceptor by D. shibae DFL12 ${ }^{\mathrm{T}}$.

For the uptake of nutrients from the environment, tripartite ATP-independent periplasmic transporters (TRAP) seem to be preferentially used by $D$. shibae DFL12 ${ }^{\mathrm{T}}$ rather than ABC-type transporters, which are only about half as frequent as in other members of the Roseobacter clade. TRAP transporters are composed of a periplasmic solute receptor (DctP or TAXI) and a secondary transporter (DctM(Q)) (Forward et al., 1997). Transport is driven by an electrochemical ion gradient rather than by ATP hydrolysis, and this may be the reason why TRAP systems have their highest prevalence among marine bacteria (Rabus et al., 1999; Mulligan et al., 2007). Their design allows the coupling of highaffinity solute reception (formerly attributed only to primary transporters) with energy-efficient ion gradient-driven permeases. The substrate range of TRAP systems also comprises, besides C4-dicarboxylates, pyruvate and two other oxoacids, glutamate, sialic acid, ectoine and 2,3-diketogulonate. With 27 complete TRAP systems encoded in its genome, D. shibae DFL $12^{\mathrm{T}}$ is second only to $S$. pomeroyi (28 complete systems). Efficient uptake of organic nutrients available only in the sub-micromolar concentration range could provide members of the Roseobacter clade with a competitive advantage.

\section{Plasmid biology}

Characteristic features of the plasmids

The most striking observation regarding the extrachromosomal elements is the long-range synteny between the 191 and the $126 \mathrm{~kb}$ plasmid (Figure 4). About $80 \%$ of the sequence of the smaller replicon, including a gene cluster of $47 \mathrm{~kb}$, a vir operon and a short inverted region (shown in blue), are highly conserved. This pattern provides strong evidence for a common origin, thus justifying their designation as sister plasmids. The differences among the nonconserved regions result from genomic rearrangements likely assisted by transposition events, an explanation that is supported by the frequent occurrence of transposases and integrases (Supplementary material S6A). Moreover, comparative sequence analyses indicate that a common ancestor of the two sister plasmids may have been recruited through conjugational gene transfer. The $D$. shibae DFL $12^{\mathrm{T}}$ chromosome has a GC content of $66 \%$, which is in the upper range of Roseobacters, and the respective values for the plasmids vary between $60 \%$ and $69 \%$ (Supplementary material S6A). The two sister plasmids show the lowest GC content and the analysis with the Artemis software revealed a poor so-called 'GC Frame Plot' (Supplementary material 6B-D). This finding probably reflects their relatively recent recruitment in an evolutionary time scale and an early stage of sequence adaptation within the new host bacterium. This scenario is supported by the observation that in $D$. shibae, ${ }_{D F L} 12^{\mathrm{T}}$ vir operons are exclusively present on the sister plasmids (Figure 4). The vir gene cluster encoding the type IV secretion system is the structural prerequisite for the formation of sex pili required for conjugation. It is structurally highly conserved among Roseobacter strains and also present in Silicibacter sp. TM1040 (Moran et al., 2007).

\section{Plasmid replication and maintenance}

We identified the core functions for plasmid replication initiation, partitioning and stability representing the 'functional heart' of a plasmid (Supplementary material 7A-C). They provide the structural basis for compatibility versus incompatibility (Petersen et al., 2009). We found three different types for replication initiation including the $\operatorname{rep} A B C$ module that is characteristic for the sister plasmids (Figure 4). Our phylogenetic analyses document that their crucial replicases $($ repC) are only distantly related, indicating that at least one of them has been exchanged by a gene transfer event. The respective $\operatorname{rep} A B C$ modules hence belong to 


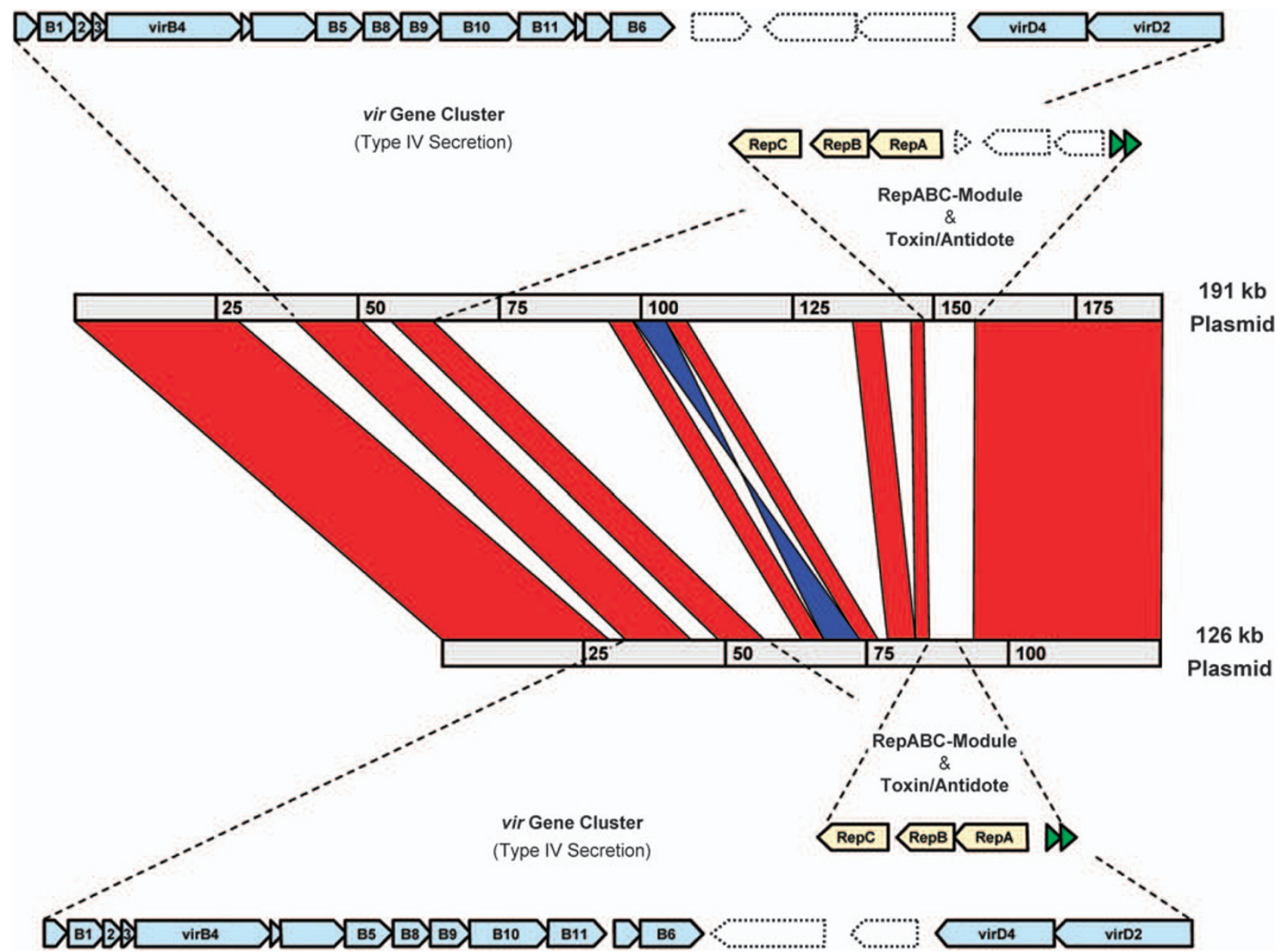

Figure 4 Synteny plot of the 191 and $126 \mathrm{~kb}$ plasmids of $D$. shibae DFL12 ${ }^{\mathrm{T}}$. Long-range homologies are shown with red bars and an inverted region is printed in blue. The left and right borders of the plasmids are completely conserved. Homologous vir clusters and the distantly related repABC-type replicons as well as the adjacent toxin/antidote addiction systems for plasmid stability are shown in detail. Adjacent genes that are not involved in plasmid core functions are indicated with dotted lines. The analysis was calculated with the Artemis Comparison Tool (WebACT, http://www.webact.org/WebACT/generate).

different compatibility groups (Petersen et al., 2009), the prerequisite for a stable coexistence of the syntenous plasmids. Finally, at least four of the five replicons contain putative addiction systems for plasmid maintenance (Zielenkiewicz and Ceglowski, 2001). They are represented by operons encoding a stable toxin as well as a less stable antidote (Figure 4). These selfish units indirectly ensure the maintenance of the low copy replicons in the offspring, as plasmid loss would be lethal for the host cell.

Metabolic capabilities and localization of genes The extrachromosomal replicons of $D$. shibae DFL $12^{\mathrm{T}}$ can roughly be classified according to their genetic composition (Supplementary material S7D). The two sister plasmids are characterized by the vir gene cluster (see above), whereas the other plasmids harbor gene clusters for the degradation of aromatic compounds (153 kb), cox operons that presumably contribute to energy production $(72 \mathrm{~kb})$ and a wealth of genes for sugar metabolism $(86 \mathrm{~kb})$. The latter replicon represents an aged and possibly dying plasmid owing to its conspicuous amount of pseudogenes and transposases. Transposition may dominate intracellular genetic rearrangements as documented for thiC, an essential gene for thiamine (vitamin $\mathrm{B}_{1}$ ) biosynthesis (Vander Horn et al., 1993). In contrast to all other genes of this pathway that are localized on the D. shibae DFL $12^{\mathrm{T}}$ chromosome, altogether three copies of thiC are located on different plasmids (191 kb, $153 \mathrm{~kb}$ and $86 \mathrm{~kb})$. The genomic neighborhood of an integrase, resolvase and transposase strongly supports an underlying dispersal mechanism based on DNA transposition.

\section{Interaction with other organisms}

Quorum sensing

D. shibae DFL $12^{\mathrm{T}}$ produces three different quorumsensing signals from the group of AHLs, namely a 
$\mathrm{C}_{8}$-homoserine lactone (C8-HSL), and two AHLs with a side chain of 18 carbon atoms, $\mathrm{C}_{18}$-en-HSL and $\mathrm{C}_{18}$-dien-HSL (Wagner-Dobler et al., 2005). This is the maximum side chain length for AHLs and it was, for the first time, detected in Sinorhizobium meliloti, a root nodule-forming symbiont (Marketon et al., 2002), where this signal downregulates motility at high cell density (Hoang et al., 2008). The unsaturations found in the $\mathrm{C}_{18}$ side chain of DFL $12^{\mathrm{T}}$ are novel and may be critical for signal specificity. The genome analysis predicted three autoinducer synthases (luxI type) and five luxR type genes for AHL-controlled transcriptional regulators (Supplementary material S3). $\operatorname{luxI}_{1}$ and $\operatorname{luxI}_{2}$ of D. shibae DFL $12^{\mathrm{T}}$ are located on the chromosome adjacent to a luxR gene with an interspacer region of appr. $100 \mathrm{~kb}$, whereas $\operatorname{luxI}_{3}$ is on the $86-\mathrm{kb}$ plasmid without an adjacent luxR gene. Roseobacter strains usually have one or two autoinducer synthases, whereas up to four have been found in root noduleforming Rhizobia (Case et al., 2008). The orphan luxR genes may allow eavesdropping on competing bacterial species in the environment (Case et al., 2008).

\section{Production of secondary metabolites}

Polyketide synthases (PKSs) catalyze the synthesis of polyketides, a large class of secondary metabolites, from acetyl-CoA precursors. D. shibae DFL12 ${ }^{\mathrm{T}}$ harbors a 12-gene cluster containing two adjacent modular type I PKS genes among hypothetical and putative proteins (Supplementary material S3). The first PKS gene is composed of only one module containing the domains essential for chain elongation ( $\beta$-ketoacylsynthase domain, acyltransferase domain, and two ACP (acyl carrier protein) domains), a 2 -nitropropane dioxygenase domain and a $\beta$-ketoacyl-ACP reductase domain. No reductive domain required for the modification of the keto-group could be identified. The second PKS gene contains two modules. In the $\mathrm{N}$-terminal module, a $\beta$-ketoacylsynthase domain and an acyltransferase domain were identified; the C-terminal module shows similarity to a phosphopantetheinyltransferase domain (PKS loading enzyme). The other genes in this cluster, such as the two putative short-chain dehydrogenases or the two putative NAD-dependent epimerases/ dehydratases, may be involved in chain modification reactions to give the final active product.

Close homologs of these genes are not found in the Roseobacter clade, but a similar gene cluster is harbored by Solibacter usitatus (Acidobacteria) and Gloeobacter violaceus (Cyanobacteria), suggesting that these genes may have been acquired by horizontal gene transfer. Thus, D. shibae DFL12 ${ }^{\mathrm{T}}$ encodes a multiprotein complex that may catalyze the synthesis of a novel polyketide that could have a role in interactions with competing microbes. The dinoflagellate surface is colonized by a range of other bacteria, including Vibrios and Flavobacteria.
Tropodithietic acid, an antibiotic produced by at least two Roseobacter isolates, is especially active against Vibrios (Brinkhoff et al., 2004; Bruhn et al., 2005) and is encoded by a different pathway (Geng et al., 2008).

\section{Resistance against viral attack}

Viruses are the most abundant biological entity on the planet (Williamson et al., 2008). By lysing a significant fraction of bacterial communities, bacteriophages influence the cycling of organic matter in the sea (Fuhrman, 1999; Weinbauer, 2004; Brussaard et al., 2008; Danovaro et al., 2008) and the genetic diversity of their host populations (Muhling et al., 2005). Continuous viral attack accompanies red tides (Tomaru and Nagasaki, 2004) and contributes to their sudden collapse (Nagasaki et al., 2005; Rhodes et al., 2008). Thus, resistance against phage attack must be highly adaptive in the habitat of $D$. shibae DFL12 ${ }^{\mathrm{T}}$, which has evolved the most complex viral defense system of all Roseobacter strains sequenced to date.

CRISPRs (clustered regularly interspaced small palindromic repeats) are small, transcribed DNA spacers separated by short palindromic repeats that are located next to a cluster of cas (CRISPR associated) genes. Many spacer sequences have been shown to originate from bacteriophages, leading to the current hypothesis that CRISPRs are involved in an RNAi-like mechanism resulting in antiviral resistance (Haft et al., 2005; Makarova et al., 2006; Barrangou et al., 2007). Two CRISPRs were detected in the genome of $D$. shibae DFL12 ${ }^{\mathrm{T}}$, whereas no other completed genome from the Rhodobacterales contains more than one. Five organisms of this group revealed a CRISPR (Supplementary material S8). Remarkably, four of them lack the characteristical CRISPR marker gene cas1, which is reportedly present in all CRISPR-containing organisms, with Pyrococcus abyssii, as formerly, a single exception. Therefore, cas1 is apparently no reliable marker for CRISPRs in the Rhodobacterales.

Figure 5 shows that the two CRISPR/cas gene clusters of $D$. shibae DFL $12^{\mathrm{T}}$ have totally different structures. Comparative sequence analyses indicated that they are complete and independent units derived from different microbial lineages. It is most likely that their acquisition occurred through horizontal gene transfer, as suggested earlier (Godde and Bickerton, 2006). To discover the origin of the CRISPR spacer sequences in D. shibae DFL $12^{\mathrm{T}}$, these sequences were compared with the marine metagenomics database, CAMERA (Seshadri et al., 2007), but no homologs were found, most likely because the habitats of $D$. shibae DFL $12^{\mathrm{T}}$ have not yet been searched for phages. Diversification of the CRISPR region is inferred to be a population-level response to the rapidly changing selective pressure of phage predation (Tyson and Banfield, 2008), and hence phage predation must represent a significant selective force in the habitat of $D$. shibae DFL $12^{\mathrm{T}}$. 


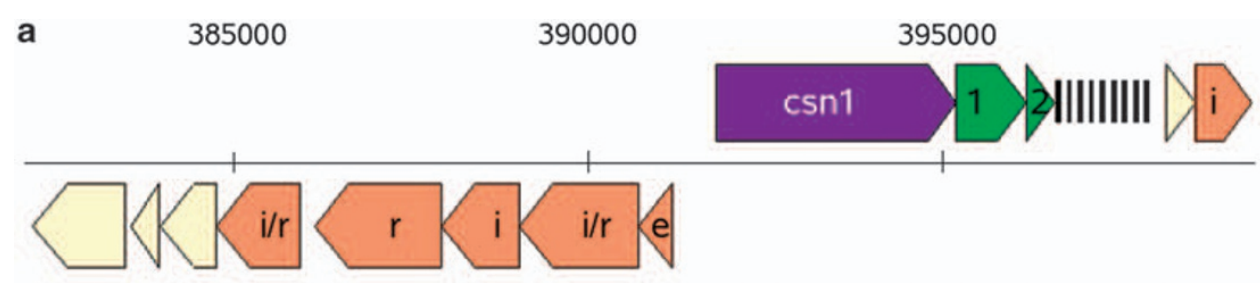

CRISPR 1: 20 repeats, consensus: AGTTTAGCTGTTCAGAATTCGGGGTCCAGCCGCAAC

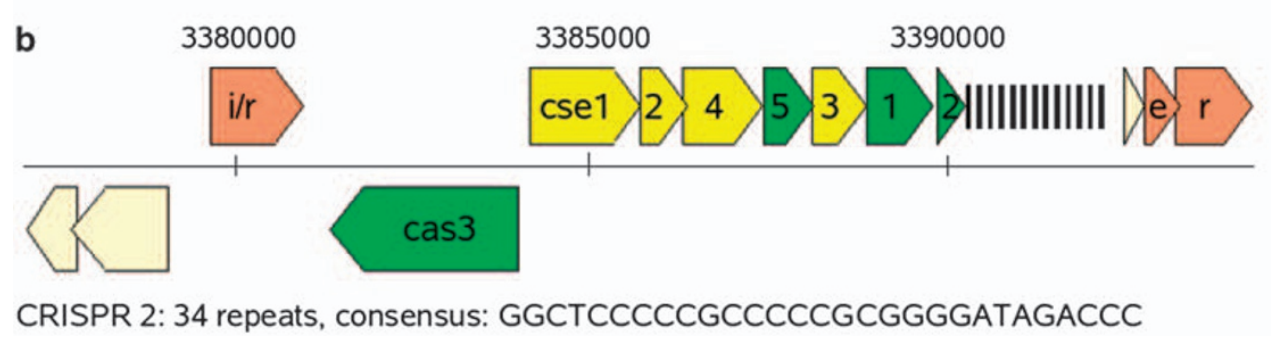

Figure 5 Genomic context of the two CRISPRs of D. shibae DFL12 ${ }^{\mathrm{T}}$. The numbers indicate the base position in the genome. Barcode-like series of vertical black bars symbolize CRISPR arrays. The colored gene arrows show the orientation, length and assignment to functional gene groups: Green—cas core genes; $1=$ cas $1 ; 2=$ cas2; $5=$ cas5. Purple-csn1 gene, specific for subtype Neisseria meningitidis. Yellow—cas genes specific for subtype Escherichia coli; $2=c s e 2 ; 3=c s e 3 ; 4=c s e 4$. Orange-genes for polynucleotide processing; $\mathrm{i}=$ integrase; $\mathrm{r}=$ recombinase; $\mathrm{e}=$ excisionase.

\section{Synthesis and utilization of vitamin $B_{12}$}

Vitamin $B_{12}$-dependent enzymatic reactions

Most Bacteria and Archaea including D. shibae DFL $12^{\mathrm{T}}$ have enzymes that require $\mathrm{B}_{12}$ as a cofactor. The genome revealed a gene encoding a $\mathrm{B}_{12^{-}}$ dependent methionine synthase, catalyzing the final step in methionine biosynthesis. A gene encoding an enzyme that catalyzes the same reaction in a $\mathrm{B}_{12}$ independent manner was also found. Genes encoding a $\mathrm{B}_{12}$-dependent ribonucleotide reductase and a methylmalonyl-CoA mutase were also found, but genes for other $\mathrm{B}_{12}$-dependent enzymes (glutamate mutase, ethanolamine ammonia lyase, diol dehydratase and glycerol dehydratase) were not present.

\section{Cobalamin biosynthesis}

Vitamin $\mathrm{B}_{12}$, which is only synthesized de novo by some Bacteria and Archaea, is derived from uroporphyrinogen III, a precursor in the synthesis of heme, siroheme, cobamides, chlorophylls and the methanogenic F430 (Scott and Roessner, 2002; Warren et al., 2002; Rodionov et al., 2003). At least 25 enzymes are uniquely involved (Roth et al., 1996). The genome of $D$. shibae DFL $12^{\mathrm{T}}$ harbors all the genes required for de novo $\mathrm{B}_{12}$ synthesis (Supplementary material S9), similar to other fully sequenced members of the Roseobacter clade, for example, R. denitrificans and S. pomeroyi. However, it has an unusual route for vitamin $\mathrm{B}_{12}$ synthesis. Two different biosynthetic routes for cobalamin are known in Bacteria: (i) an oxygen-dependent (aerobic) pathway and (ii) an oxygen-independent (anaerobic) pathway (Martens et al., 2002; Scott and Roessner, 2002; Warren et al., 2002). They differ in the first part, the insertion of cobalt into the corrin ring, whereas the second part is common for both the routes. In the aerobic route, cobalt insertion is performed by an ATP-dependent cobalt chelatase, which is encoded in P. denitrificans by cobN, cobS and cobT. In the anaerobic pathway, single subunit ATP-independent cobalt chelatases such as CbiX of $B$. megaterium are performing the reaction. D. shibae DFL $12^{\mathrm{T}}$ contains putative genes for both types of chelatases and in this respect it is unique among the fully sequenced Rhodobacterales. Other pathwayspecific genes were also present, but $c o b G$, regarded as a signature gene for the aerobic route (Scott and Roessner, 2002), was absent. The gene for an alternative enzyme found in Rhodobacter capsulatus, CobZ, was also not present (McGoldrick et al., 2005). Thus, D. shibae DFL12 ${ }^{\mathrm{T}}$ might have the property to synthesize $B_{12}$ by either the aerobic or the anaerobic pathway depending on the availability of oxygen. Alternatively, it might synthesize $B_{12}$ by an unusual combination of both pathways.

We experimentally confirmed that the de novo pathway for vitamin $\mathrm{B}_{12}$ synthesis is functional in $D$. shibae DFL12 ${ }^{\mathrm{T}}$. The bacteria can grow in a defined mineral medium, but to exclude that traces of vitamin $B_{12}$ might be present even in such media, we compared the $B_{12}$ content of cells grown in the presence and absence of methionine. D. shibae DFL12 ${ }^{\mathrm{T}}$ has two methionine synthases, one requiring $\mathrm{B}_{12}$ and another that is $\mathrm{B}_{12}$ independent. In the absence of methionine, the content of $\mathrm{B}_{12}$ in the cells should increase, as the $\mathrm{B}_{12}$-dependent methionine synthase requires $B_{12}$ as a cofactor. The vitamin $B_{12}$ content of the cells was $340 \pm 36 \mathrm{ng} \mathrm{mg}^{-1}$ protein in the presence of methionine and increased to $450 \pm 26 \mathrm{ng} \mathrm{mg}^{-1}$ protein in the absence of methio- 


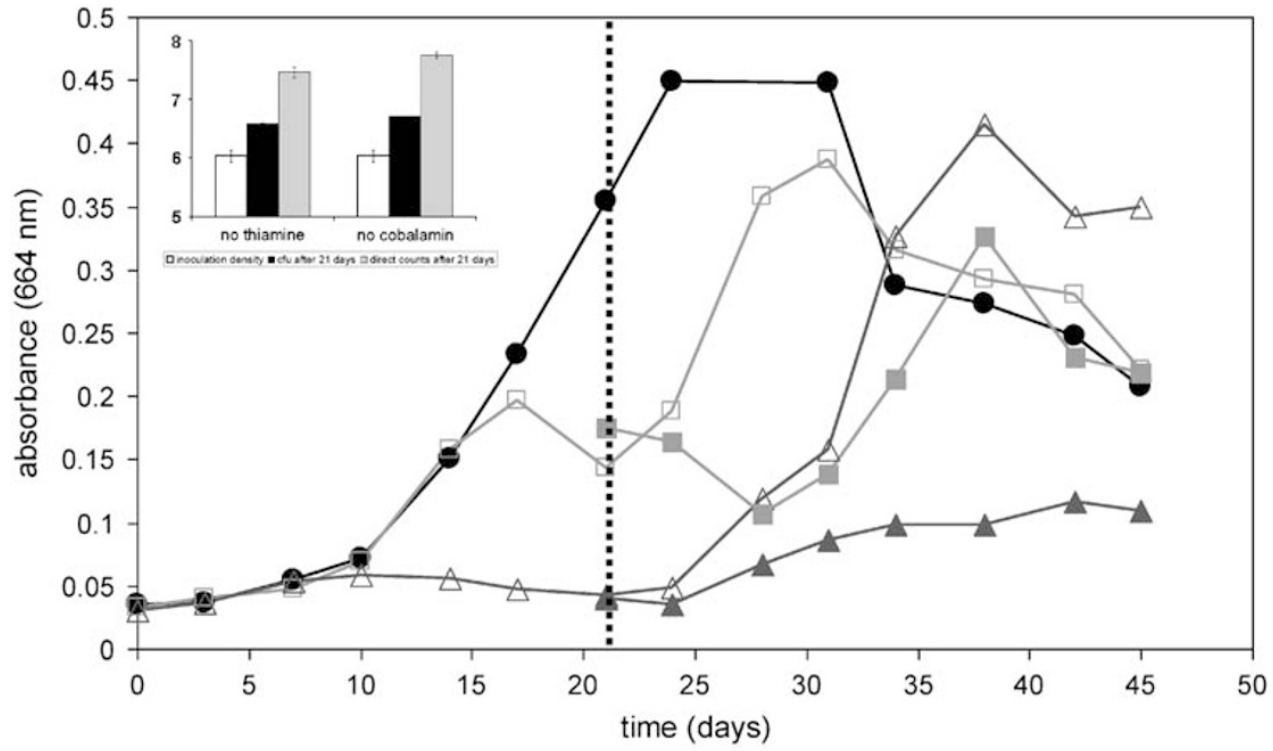

Figure 6 The bacterium $D$. shibae DFL12 ${ }^{\mathrm{T}}$ provides thiamine $\left(\mathrm{B}_{1}\right)$ and cobalamin $\left(\mathrm{B}_{12}\right)$ to the dinoflagellate Prorocentrum minimum in coculture. Growth of the algae is shown as the amount of chlorophyll a (absorbance at $664 \mathrm{~nm}$ ). Symbols show cultures on L1 mineral salts medium $\Delta$ lacking thiamine; $\square$ lacking cobalamin and $\bullet$ control (complete L1 medium). On day 22 (dotted line), $1 \%$ of the cultures lacking thiamine or cobalamin were transferred to fresh medium of the same composition. One half of the culture was provided with the lacking vitamin (open symbols), and the other half was inoculated with $D$. shibae DFL12 ${ }^{\mathrm{T}}$ (filled symbols). The inset shows log cell densities of $D$. shibae DFL $12^{\mathrm{T}}$ at the time of inoculation and at the end of the experiment (cfu and direct microscopic counts). A full colour version of this figure is available at The ISME Journal online.

nine, showing that a complete de novo pathway for vitamin $\mathrm{B}_{12}$ synthesis is functional.

\section{Symbiosis with dinoflagellates}

Besides supplying its own $\mathrm{B}_{12}$-dependent enzymes with the cofactor, the versatility in $\mathrm{B}_{12}$ production might also contribute to a successful symbiosis with the dinoflagellate. Axenic (bacteria-free) cultures of dinoflagellates can be obtained on defined mineral media, but supplementation with three vitamins is necessary, namely thiamine $\left(\mathrm{B}_{1}\right)$, cobalamin $\left(\mathrm{B}_{12}\right)$ and biotin $\left(\mathrm{B}_{7}\right.$ or vitamin $\mathrm{H}$ ) (Guillard and Hargraves, 1993). D. shibae DFL12 ${ }^{\mathrm{T}}$ is able to synthesize two of these, $B_{12}$ and $B_{1}$. It is auxotrophic for biotin, similar to many Roseobacter species (Shiba, 1991), and thus this vitamin must be provided by other sources in nature to both the dinoflagellate and the Roseobacter species.

To experimentally determine whether $D$. shibae DFL $12^{\mathrm{T}}$ can provide $\mathrm{B}_{1}$ and $\mathrm{B}_{12}$ to its dinoflagellate host, we performed coculture experiments. Axenic cultures for $P$. lima are not available in culture collections, but as the symbiosis of $D$. shibae with algae is not strictly host specific, we reasoned that proof of principle might be obtained using the closely related dinoflagellate $P$. minimum CCMP1329.

First, auxotrophy of $P$. minimum for $\mathrm{B}_{1}$ and $\mathrm{B}_{12}$ was investigated, as it had not been tested earlier (Croft et al., 2005). Supplementary material S10 shows that $P$. minimum was not able to grow on a synthetic mineral medium from which either $B_{1}$ or $\mathrm{B}_{12}$ had been omitted. Next, either $\mathrm{B}_{1}$ or $\mathrm{B}_{12}$ were replaced by $1.1 \times 10^{6}$ cells per $\mathrm{ml}$ of $D$. shibae
DFL12 ${ }^{\mathrm{T}}$. In the experiment shown in Figure 6, the dinoflagellate was first cultivated for 22 days without bacteria; there was no growth without thiamine, and cobalamin became growth limiting after about 17 days. On day 22, the cultures were divided. One half was provided with the lacking vitamin, and the other half was inoculated with D. shibae DFL12 ${ }^{\mathrm{T}}$. Figure 6 shows that $D$. shibae DFL $12^{\mathrm{T}}$ stimulated the growth of the alga in the absence of $\mathrm{B}_{1}$ or $\mathrm{B}_{12}$, and that the alga allowed the bacterium to grow too (inlay in Figure 6). From an initial density of $1.1 \times 10^{6} \mathrm{cfu} \mathrm{ml}^{-1}$, they increased to $5.1 \times 10^{6} \mathrm{cfu} \mathrm{ml}^{-1}$. Bacterial densities determined by direct microscopic counts were even higher by more than one order of magnitude. The density of the dinoflagellate at the end of the experiment was appr. $2.5 \times 10^{6}$ cells $\mathrm{ml}^{-1}$, as determined by microscopic counts. Supplementation with pure vitamins resulted in faster recovery of the dinoflagellate culture in the case of $\mathrm{B}_{12}$, and in much stronger recovery in the case of $\mathrm{B}_{1}$ compared with inoculation with $D$. shibae DFL12 ${ }^{\mathrm{T}}$. The bacteria were entirely dependent on carbon sources excreted by the algae, and thus may have been initially starved in the non-growing algal culture. The concentration of thiamine present in the cultivation medium is 200 -fold higher than that of $\mathrm{B}_{12}$, and therefore the amount synthesized by the relatively low density of bacteria might not have been sufficient.

Experiments with the haptophyte I. galbana CCMP1323, from which $D$. shibae DFL $12^{\mathrm{T}}$ has also been isolated and which is known to be auxotrophic for $\mathrm{B}_{12}$ (Croft et al., 2005), showed similar results for cobalamin, but this alga did not require thiamine for 

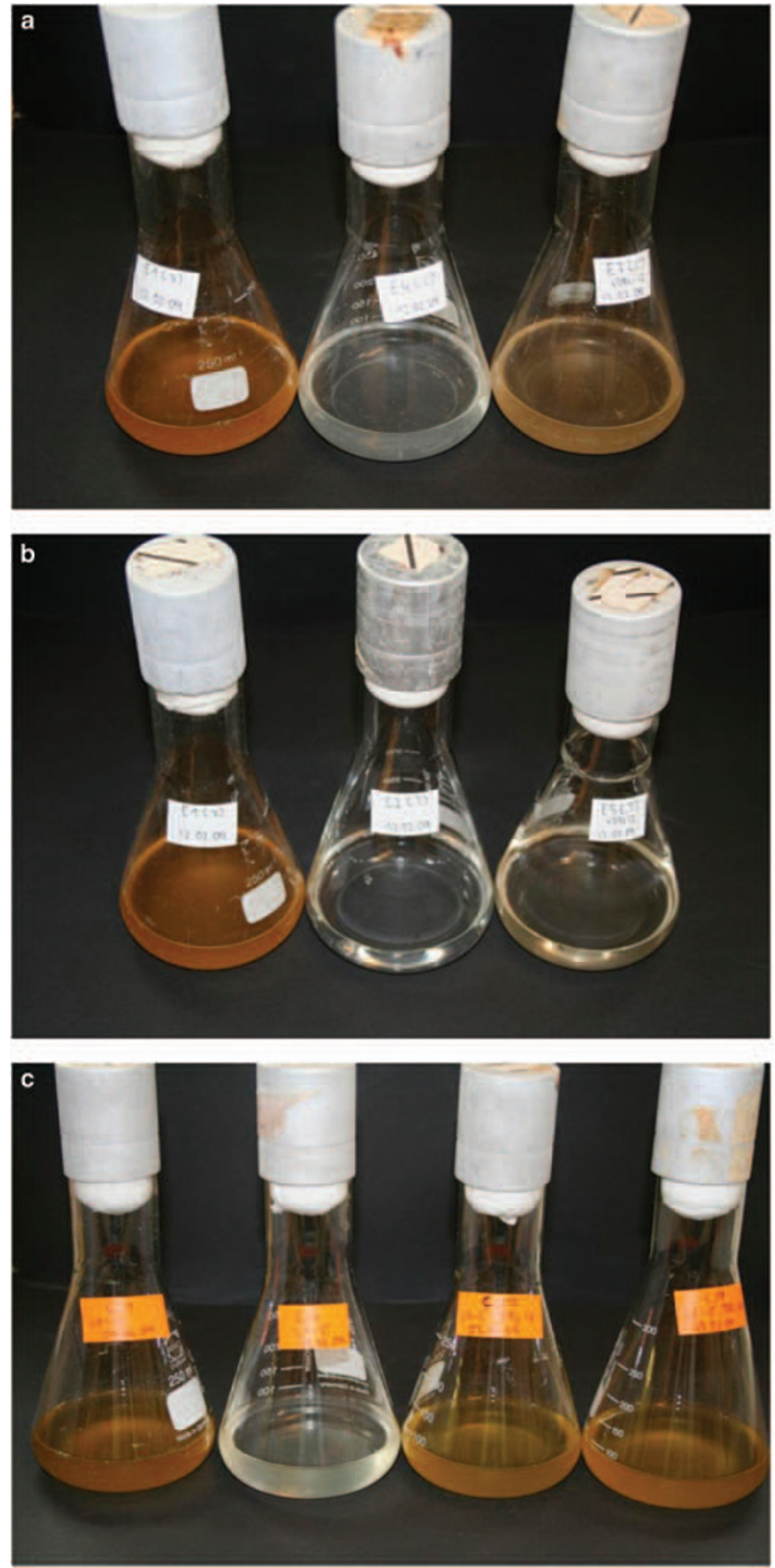

\section{Prorocentrum minimum} CCMP1329.

Media are (from left to right) L1 medium, L1 medium lacking cobalamin, and L1 medium lacking cobalamin inoculated with $D$. shibae DFL12 ${ }^{\top}$.

\section{Prorocentrum minimum} CCMP1329.

Media are (from left to right) L1 medium, L1 medium lacking thiamine, and L1 medium lacking thiamine inoculated with $D$. shibae DFL12' .

\section{Isochrysis galbana} CCMP1323.

Media are (from left to right) L1 medium, L1 medium lacking cobalamin, L1 medium lacking cobalamin inoculated with $10 \mu \mathrm{l}$ $D$. shibae $\mathrm{DFL} 12^{\mathrm{T}}$ and $\mathrm{L} 1$ medium lacking cobalamin inoculated with $100 \mu \mathrm{l} D$. shibae DFL12 ${ }^{\top}$

Figure 7 Cultures of the axenic dinoflagellate Prorocentrum minimum CCMP1329 (a and b) and the axenic haptophyte Isochrysis galbana CCMP1323 (c) inoculated with D. shibae DFL12 ${ }^{\mathrm{T}}$ in the absence of vitamin $\mathrm{B}_{12}$ and (a and $\left.\mathbf{c}\right)$ or vitamin $\mathrm{B}_{1}(\mathbf{b})$.

growth. Figure 7 shows the effects of cocultivation with $D$. shibae DFL $12^{\mathrm{T}}$ on cultures of P. minimum and I. galbana in media lacking cobalamin or thiamine.

\section{Discussion}

Adaptation to periodic anoxia

D. shibae DFL $12^{\mathrm{T}}$ is clearly optimized for respiratory modes of energy conservation. Its electron transport systems are fueled both by organic carbon com- pounds and light, with ubiquinone as a central intermediate pool. However, the arginine deiminase survival fermentation pathway and the ability to use alternative electron acceptors (nitrate, DSMO) allow D. shibae DFL $12^{\mathrm{T}}$ to sustain an active energy metabolism in the complete absence of oxygen. Several of the key genes involved are also found in other Roseobacter species. Therefore, the current paradigm that the Roseobacter clade comprises only obligate aerobes needs to be revised. Periodic anoxia is regularly encountered in photosynthetic biofilms at night as a result of intense respiration, as shown, 
for example, for microbial mats (Steunou et al., 2008). Moreover, steep gradients of oxygen and nitrate are present in marine sediments (Lorenzen et al., 1998), and as microorganisms are easily transported by bioturbation to deeper layers (Pischedda et al., 2008), the ability of $D$. shibae DFL12 ${ }^{\mathrm{T}}$ to switch between alternative electron acceptors is crucial.

D. shibae DFL12 $2^{T}$ is able to provide the dinoflagellate host with vitamins

The genome data suggest that $D$. shibae $\mathrm{DFL} 12^{\mathrm{T}}$ is able to synthesize two nutrients that are essential and potentially growth limiting for their hosts, vitamin $\mathrm{B}_{12}$ (cobalamin) and vitamin $\mathrm{B}_{1}$ (thiamine). The pathways for both of them have unique features: Altogether, three copies of the thiamine synthetase, thiC, are present on different plasmids $(191 \mathrm{~kb}$, $153 \mathrm{~kb}$ and $86 \mathrm{~kb}$ ), whereas all the other thiamine synthesis genes are located on the chromosome. Synthesis of vitamin $\mathrm{B}_{12}$ should be possible by an oxygen-dependent as well as an oxygen-independent pathway in D. shibae DFL12 ${ }^{\mathrm{T}}$, whereas organisms studied to date use only one of these pathways, pointing to both the importance of anaerobic conditions in the life of $D$. shibae DFL12 ${ }^{\mathrm{T}}$ and to the importance of $\mathrm{B}_{12}$.

We experimentally confirmed that a pathway for de novo synthesis of $\mathrm{B}_{12}$ is functional in $D$. shibae DFL $12^{\mathrm{T}}$ and that the bacteria can provide both $\mathrm{B}_{1}$ and $\mathrm{B}_{12}$ to the dinoflagellate $P$. minimum in a defined coculture. Thus, a symbiotic relationship between $D$. shibae $\mathrm{DFL} 12^{\mathrm{T}}$ and its dinoflagellate host may exist, which is based on an exchange of micronutrients synthesized at extremely low concentrations but high metabolic costs by the bacteria against photosynthate leaking from the algae during photosynthesis. As D. shibae is associated with several phylogenetically diverse species of algae, this symbiosis is not host specific. The dinoflagellate may replace $D$. shibae with other bacteria, provided they carry out the same essential functions, for example, synthesize $\mathrm{B}_{12}$. Conversely, $D$. shibae may live with another algae if it excretes photosynthate, dimethylsulfoniopropionate and so on A variety of symbioses ranging from loose mutualistic interactions to obligate endosymbiotic relationships are increasingly discovered on the basis of genomic data and novel experimental methods (Moran, 2006). However, D. shibae DFL12 ${ }^{\mathrm{T}}$ could also be a scavenger of dead algae during the collapse of algal blooms. The metabolic flexibility as shown in the genome suggests that it might even switch from a symbiotic to a parasitic mode of life.

\section{Growth limitation of phytoplankton by vitamins in} the sea

Although $50 \%$ of all dinoflagellate species require $\mathrm{B}_{12}$, they may not be dependent on a symbiosis with bacteria to obtain it (Croft et al., 2005), as the requirements are so low that ambient concentrations in seawater may suffice (Droop, 2007). New methods have been used to determine the pmolar concentrations of $\mathrm{B}_{1}$ and $\mathrm{B}_{12}$ in situ (Okbamichael and Sanudo-Wilhelmy, 2005). $\mathrm{B}_{12}$ concentrations correlate with bacterial densities at certain times and in some locations and decreased 90\% during dinoflagellate blooms, relative to pre-bloom values (Gobler et al., 2007). $\mathrm{B}_{12}$ colimitation with iron was, for the first time, shown in coastal waters of the Antarctic peninsula (Panzeca et al., 2006) and later on in the Ross Sea, one of the most productive areas in the Southern Ocean (Bertrand et al., 2007). In this study, the bacterial densities are low; cyanobacteria, which are able to synthesize $B_{12}$, are absent, and UV irradiance is high, all accounting for low ambient levels of $\mathrm{B}_{12}$. These phytoplankton communities were iron limited, but adding $\mathrm{B}_{12}$ together with iron resulted in an additional increase in biomass. One of the dominant dinoflagellates present at the time was $P$. minimum, which was shown here to be auxotrophic for $\mathrm{B}_{12}$, supporting the results of Bertrand et al. Thus, $\mathrm{B}_{12}$ can clearly be growth limiting in the sea under certain conditions. The composition of the bacterial flora may therefore have consequences for the succession of phytoplankton species (Panzeca et al., 2008). Field investigations of bacterial communities associated with algae at such a level of detail, deciphering not only phylogenetic composition but also metabolic function, have not yet been carried out, but the breathtaking progress of sequencing whole microbial communities (Nealson and Venter, 2007) and, in the future, even single cells will eventually change this.

Horizontal and vertical gene transfer and the adaptive Roseobacter gene pool

The members of the Roseobacter clade are characterized by a significant fraction of extrachromosomal elements in their genomes (Pradella et al., 2004), with $D$. shibae DFL $12^{\mathrm{T}}$ currently housing the largest number of plasmids among the fully sequenced strains. Conjugation obviously has a crucial role in the horizontal spread of these genetic elements, even if the experimental proof is still lacking. A conspicuous example is the presence of a $47-\mathrm{kb}$ gene cluster on the two sister plasmids of $D$. shibae DFL12 ${ }^{\mathrm{T}}$ and on several other extrachromosomal elements of the Roseobacter clade, which also harbor the vir gene cluster required for conjugation. Genes that have been found on Roseobacter plasmids include not only typical plasmid-encoded traits such as degradation of aromatic compounds, but also key genes for biogeochemical cycles, for example, carbon monoxide oxidation in D. shibae DFL $12^{\mathrm{T}}$ and even the complete photosynthesis gene cluster in $R$. litoralis ((Pradella et al., 2004) and integrated microbial genomes). The horizontal transfer of these traits within the Roseobacter clade is 
consistent with their patchwork distribution in the phylogenetic tree (Buchan et al., 2005). Our data show that the boundary between the chromosome and the plasmid is dynamic, as outsourcing of chromosomal genes to plasmids can be observed and increases the shared adaptive gene pool in the lineage.

Besides plasmids, phages also may mediate horizontal gene transfer. In total, $5 \%$ of the genome of $S$. TM1040 consists of prophages (Chen et al., 2006; Moran et al., 2007). A phage-like structure, the so-called GTA (gene transfer agent), was discovered many years ago in Rh. capsulatus. GTA particles contain only a few kilobases of DNA, are not inducible by mitomycin and do not form plaques. They contain small random pieces of host DNA, rather than a phage genome, suggesting that their main activity is the lateral transfer of host DNA. A search for the 15 GTA genes from Rh. capsulatus in complete and draft bacterial genomes showed that they are exclusively present in Alphaproteobacteria, and that all but one of the genome sequences in the Roseobacter clade have a GTA-like gene cluster, including D. shibae DFL12 ${ }^{\mathrm{T}}$ (Biers et al., 2008). Thus, the genetic adaptability of the Roseobacter gene pool appears to be because of the richness of extrachromosomal elements, some of which are conjugative, the mobilization of genes from the chromosome to the plasmid, and a phagelike gene transfer mechanism unique in Alphaproteobacteria.

\section{Outlook}

Roseobacter bacteria are often associated with marine algae and reach high abundances during algal blooms. Our findings shed new light on this association, suggesting that it might be a symbiotic relationship in which a bacterium is required by the alga for the supply of essential nutrients, which can be growth limiting under certain conditions. Conversely, the bacteria may scavenge on dead algae and possibly switch between both types of interactions.

Studying the specificity and molecular mechanisms of this relationship in detail, both in the laboratory and in the sea, remains a fascinating field for future analyses.

\section{Acknowledgements}

Jonathan Eisen is most gratefully acknowledged for helpful comments on an earlier version of this paper. Many thanks to the computer department at HZI for providing the facilities for the genome jamboree, and to all employes at JGI for fast and efficient feedback and support at all times. Special thanks to Tracey Riggens at the ProvasoliGuillard Center for Culture of Marine Phytoplankton (CCMP), Maine, USA, and Maike Lorenz at the Experimental Phycology and Culture Collection of Algae (SAG), Göttingen, Germany, for sending the algal cultures so promptly! Finally, the skillful technical assistance of Bettina Elxnat is very much appreciated.

We thank the Ministry of Science and Culture (MWK), Lower Saxony, Germany and the Lower Saxonian Branch of the Volkswagen Foundation for financial support within the priority program on Marine Biotechnology (ZN1225) and within the program 'Comparative Genome Anlysis of Representative Members of the Roseobacter Clade' (ZN2235). The help of the Moore Foundation, USA. is gratefully acknowledged. Sequencing and finishing of D. shibae DFL12 ${ }^{\mathrm{T}}$ were performed under the auspices of the US Department of Energy's Office of Science, Biological and Environmental Research Program and by the University of California, Lawrence Livermore National Laboratory under Contract No. W-7405-Eng-48, Lawrence Berkeley National Laboratory under contract No. DEAC03-76SF00098 and Los Alamos National Laboratory under contract No. W-7405-ENG-36.

\section{References}

Aasen J, Samdal IA, Miles CO, Dahl E, Briggs LR, Aune T. (2005). Yessotoxins in Norwegian blue mussels (Mytilus edulis): uptake from Protoceratium reticulatum, metabolism and depuration. Toxicon 45 : 265-272.

Alavi M, Miller T, Erlandson K, Schneider R, Belas R. (2001). Bacterial community associated with Pfiesterialike dinoflagellate cultures. Environ Microbiol 3: 380-396.

Allgaier M, Uphoff H, Felske A, Wagner-Dobler I. (2003). Aerobic anoxygenic photosynthesis in Roseobacter clade bacteria from diverse marine habitats. Appl Environ Microbiol 69: 5051-5059.

Altschul SF, Gish W, Miller W, Myers EW, Lipman DJ. (1990). Basic local alignment search tool. J Mol Biol 215: 403-410.

Aluwihare LI, Repeta DJ, Chen RF. (2002). Chemical composition and cycling of dissolved organic matter in the Mid-Atlantic bight. Deep Sea Res Part II Top Stud Oceanogr 49: 4421-4437.

Azam F, Fenchel T, Gray JS, Meyer-Reill LA, Thingstad F. (1983). The ecological role of water-column microbes in the sea. Mar Ecol Prog Ser 10: 257-263.

Barrangou R, Fremaux C, Deveau H, Richards M, Boyaval P, Moineau S et al. (2007). CRISPR provides acquired resistance against viruses in prokaryotes. Science $\mathbf{3 1 5}$ : 1709-1712.

Bertrand EM, Saito MA, Rose JM, Riesselman CR, Lohan MC, Noble AE et al. (2007). Vitamin B-12 and iron colimitation of phytoplankton growth in the Ross sea. Limnol Oceanogr 52: 1079-1093.

Biebl H, Allgaier M, Tindall BJ, Koblizek M, Luensdorf H, Pukall R et al. (2005). Dinoroseobacter shibae gen. nov., sp. nov., a new aerobic phototrophic bacterium isolated from dinoflagellates. Int J Syst Evol Microbiol 55: 1089-1096.

Biebl H, Wagner-Dobler I. (2006). Growth and bacteriochlorophyll $a$ formation in taxonomically diverse aerobic anoxygenic phototrophic bacteria in chemostat culture: influence of light regimen and starvation. Process Biochem 41: 2153-2159.

Biers EJ, Wang K, Pennington C, Belas R, Chen F, Moran MA. (2008). Occurrence and expression of 
gene transfer agent genes in marine bacterioplankton. Appl Environ Microbiol 74: 2933-2939.

Biersmith A, Benner R. (1998). Carbohydrates in phytoplankton and freshly produced dissolved organic matter. Mar Chem 63: 131-144.

Bland C, Ramsey TL, Sabree F, Lowe M, Brown K, Kyrpides NC et al. (2007). CRISPR recognition tool (CRT): a tool for automatic detection of clustered regularly interspaced palindromic repeats. BMC Bioinformatics 8: 209.

Brinkhoff T, Bach G, Heidorn T, Liang L, Schlingloff A, Simon M. (2004). Antibiotic production by a Roseobacter clade-affiliated species from the German Wadden Sea and its antagonistic effects on indigenous isolates. Appl Environ Microbiol 70: 2560-2565.

Brinkhoff T, Giebel HA, Simon M. (2008). Diversity, ecology, and genomics of the Roseobacter clade: a short overview. Arch Microbiol 189: 531-539.

Bruhn JB, Nielsen KF, Hjelm M, Hansen M, Bresciani J, Schulz S et al. (2005). Ecology, inhibitory activity, and morphogenesis of a marine antagonistic bacterium belonging to the Roseobacter clade. Appl Environ Microbiol 71: 7263-7270.

Brussaard CP, Wilhelm SW, Thingstad F, Weinbauer MG, Bratbak G, Heldal M et al. (2008). Global-scale processes with a nanoscale drive: the role of marine viruses. ISME J 2: 575-578.

Buchan A, Gonzalez JM, Moran MA. (2005). Overview of the marine Roseobacter lineage. Appl Environ Microbiol 71: 5665-5677.

Case RJ, Labbate M, Kjelleberg S. (2008). AHL-driven quorum-sensing circuits: their frequency and function among the Proteobacteria. ISME J 2: 345-349.

Chen F, Wang K, Stewart J, Belas R. (2006). Induction of multiple prophages from a marine bacterium: a genomic approach. Appl Environ Microbiol 72: 4995-5001.

Choudhary M, Zanhua X, Fu YX, Kaplan S. (2007). Genome analyses of three strains of Rhodobacter sphaeroides: evidence of rapid evolution of chromosome II. J Bacteriol 189: 1914-1921.

Croft MT, Lawrence AD, Raux-Deery E, Warren MJ, Smith AG. (2005). Algae acquire vitamin B12 through a symbiotic relationship with bacteria. Nature 438: 90-93.

Danovaro R, Dell'Anno A, Corinaldesi C, Magagnini M, Noble R, Tamburini C et al. (2008). Major viral impact on the functioning of benthic deep-sea ecosystems. Nature 454: 1084-1087.

Droop MR. (2007). Vitamins, phytoplankton and bacteria: symbiosis or scavenging? J Plankton Res 29: 107-113.

Eschbach M, Schreiber K, Trunk K, Buer J, Jahn D, Schobert M. (2004). Long-term anaerobic survival of the opportunistic pathogen Pseudomonas aeruginosa via pyruvate fermentation. J Bacteriol 186: 4596-4604.

Ewing B, Green P. (1998). Base-calling of automated sequencer traces using phred. II. Error probabilities. Genome Res 8: 186-194.

Ewing B, Hillier L, Wendl MC, Green P. (1998). Basecalling of automated sequencer traces using phred. I. Accuracy assessment. Genome Res 8: 175-185.

Forward JA, Behrendt MC, Wyborn NR, Cross R, Kelly DJ. (1997). TRAP transporters: a new family of periplasmic solute transport systems encoded by the dctPQM genes of Rhodobacter capsulatus and by homologs in diverse gram-negative bacteria. J Bacteriol 179: 5482-5493.
Fuhrman JA. (1999). Marine viruses and their biogeochemical and ecological effects. Nature 399: 541-548.

Fürch T, Preusse M, Tomasch J, Zech H, Wagner-Dobler I, Rabus R et al. (2009). Metabolic fluxes in the central carbon metabolism of Dinoroseobacter shibae and Phaeobacter gallaeciensis, to members of the marine Roseobacter clade. submitted to BMC Microbiology.

Geng H, Bruhn JB, Nielsen KF, Gram L, Belas R. (2008). Genetic dissection of tropodithietic acid biosynthesis by marine roseobacters. Appl Environ Microbiol 74: 1535-1545.

Gevers D, Cohan FM, Lawrence JG, Spratt BG, Coenye T, Feil EJ et al. (2005). Opinion: re-evaluating prokaryotic species. Nat Rev Microbiol 3: 733-739.

Gobler CJ, Norman C, Panzeca C, Taylor GT, SanudoWilhelmy SA. (2007). Effect of B-vitamins (B1, B12) and inorganic nutrients on algal bloom dynamics in a coastal ecosystem. Aquat Microb Ecol 49: 181-194.

Godde JS, Bickerton A. (2006). The repetitive DNA elements called CRISPRs and their associated genes: evidence of horizontal transfer among prokaryotes. J Mol Evol 62: 718-729.

Gordon D, Abajian C, Green P. (1998). Consed: a graphical tool for sequence finishing. Genome Res 8: 195-202.

Grissa I, Vergnaud G, Pourcel C. (2007). The CRISPRdb database and tools to display CRISPRs and to generate dictionaries of spacers and repeats. BMC Bioinformatics 8: 172.

Guillard RRL, Hargraves PE. (1993). Stichochrysis immobilis is a diatom, not a chrysophyte. Phycologia 32: 234-236.

Haft DH, Selengut J, Mongodin EF, Nelson KE. (2005). A guild of 45 CRISPR-associated (Cas) protein families and multiple CRISPR/Cas subtypes exist in prokaryotic genomes. PLoS Comput Biol 1: e60.

Han CS, Chain P. (2006). Finishing repeat regions automatically with Dupfinisher Arabnia, H. R. and Valafar H. 141-146. CSREA Press. Proceedings of the 2006 International Conference on Bioinformatics \& Computational Biology. 26-6-2006.

Hasegawa Y, Martin JL, Giewat MW, Rooney-Varga JN. (2007). Microbial community diversity in the phycosphere of natural populations of the toxic alga, Alexandrium fundyense. Environ Microbiol 9: 3108-3121.

Hoang HH, Gurich N, lez JE. (2008). Regulation of motility by the ExpR/Sin quorum-sensing system in Sinorhizobium meliloti. J Bacteriol 190: 861-871.

Howard EC, Henriksen JR, Buchan A, Reisch CR, Burgmann H, Welsh R et al. (2006). Bacterial taxa that limit sulfur flux from the ocean. Science 314: 649-652.

Kobryn K, Chaconas G. (2001). The circle is broken: telomere resolution in linear replicons. Curr Opin Microbiol 4: 558-564.

Kowalik K. (1969). The crystal lattice of the pyrenoid matrix of Prorocentrum micans. J Cell Sci 5: 251-269.

Lafay B, Ruimy R, de Traubenberg CR, Breittmayer V, Gauthier MJ, Christen R. (1995). Roseobacter algicola sp. nov., a new marine bacterium isolated from the phycosphere of the toxin-producing dinoflagellate Prorocentrum lima. Int J Syst Bacteriol 45: 290-296.

Levasseur M, Couture JY, Weise AM, Michaud S, Elbraechter M, Sauve G et al. (2003). Pelagic and epiphytic summer distributions of Prorocentrum lima and $P$. mexicanum at two mussel farms in the Gulf of St. Lawrence, Canada. Aquat Microb Ecol 30: 283-293.

Lorenzen J, Larsen LH, Kjaer T, Revsbech NP. (1998). Biosensor determination of the microscale distribution 
of nitrate, nitrate assimilation, nitrification, and denitrification in a diatom-inhabited freshwater sediment. Appl Environ Microbiol 64: 3264-3269.

Ludwig W, Strunk O, Westram R, Richter L, Meier H, Yadhukumar et al. (2004). ARB: a software environment for sequence data. Nucleic Acids Res 32: 1363-1371.

Makarova KS, Grishin NV, Shabalina SA, Wolf YI, Koonin EV. (2006). A putative RNA-interference-based immune system in prokaryotes: computational analysis of the predicted enzymatic machinery, functional analogies with eukaryotic RNAi, and hypothetical mechanisms of action. Biol Direct 1: 7.

Marketon MM, Gronquist MR, Eberhard A, lez JE. (2002). Characterization of the Sinorhizobium meliloti sinR/ sinI locus and the production of novel N-acyl homoserine lactones. J Bacteriol 184: 5686-5695.

Markowitz VM, Szeto E, Palaniappan K, Grechkin Y, Chu K, Chen IM et al. (2008). The integrated microbial genomes (IMG) system in 2007: data content and analysis tool extensions. Nucleic Acids Res 36: D528-D533.

Martens JH, Barg H, Warren MJ, Jahn D. (2002). Microbial production of vitamin B12. Appl Microbiol Biotechnol 58: 275-285.

Mayali X, Franks PJ, Azam F. (2008). Cultivation and ecosystem role of a marine Roseobacter clade-affiliated cluster bacterium. Appl Environ Microbiol 74: 2595-2603.

McGoldrick HM, Roessner CA, Raux E, Lawrence AD, McLean KJ, Munro AW et al. (2005). Identification and characterization of a novel vitamin B12 (cobalamin) biosynthetic enzyme (CobZ) from Rhodobacter capsulatus, containing flavin, heme, and Fe-S cofactors. J Biol Chem 280: 1086-1094.

Meinhardt F, Schaffrath R, Larsen M. (1997). Microbial linear plasmids. Appl Microbiol Biotechnol 47: 329-336.

Miller TR, Belas R. (2004). Dimethylsulfoniopropionate metabolism by Pfiesteria-associated Roseobacter spp. Appl Environ Microbiol 70: 3383-3391.

Miller TR, Belas R. (2006). Motility is involved in Silicibacter sp. TM 1040 interaction with dinoflagellates. Environ Microbiol 8: 1648-1659.

Miller TR, Hnilicka K, Dziedzic A, Desplats P, Belas R. (2004). Chemotaxis of Silicibacter sp. strain TM1040 toward dinoflagellate products. Appl Environ Microbiol 70: 4692-4701.

Moran MA, Belas R, Schell MA, Gonzalez JM, Sun F, Sun $S$ et al. (2007). Ecological genomics of marine Roseobacters. Appl Environ Microbiol 73: 4559-4569.

Moran MA, Buchan A, Gonzalez JM, Heidelberg JF, Whitman WB, Kiene RP et al. (2004). Genome sequence of Silicibacter pomeroyi reveals adaptations to the marine environment. Nature 432: 910-913.

Moran MA, Miller WL. (2007). Resourceful heterotrophs make the most of light in the coastal ocean. Nat Rev Microbiol 5: 792-800.

Moran NA. (2006). Symbiosis. Curr Biol 16: R866-R871.

Muhling M, Fuller NJ, Millard A, Somerfield PJ, Marie D, Wilson WH et al. (2005). Genetic diversity of marine Synechococcus and co-occurring cyanophage communities: evidence for viral control of phytoplankton. Environ Microbiol 7: 499-508.

Mulligan C, Kelly DJ, Thomas GH. (2007). Tripartite ATP-independent periplasmic transporters: application of a relational database for genome-wide analysis of transporter gene frequency and organization. J Mol Microbiol Biotechnol 12: 218-226.

Munch R, Hiller K, Grote A, Scheer M, Klein J, Schobert M et al. (2005). Virtual Footprint and PRODORIC: an integrative framework for regulon prediction in prokaryotes. Bioinformatics 21: 4187-4189.

Nagasaki K, Takao Y, Shirai Y, Mizumoto H, Tomaru Y. (2005). Molecular ecology of microalgal viruses. Uirusu 55: 127-132.

Nealson KH, Venter JC. (2007). Metagenomics and the global ocean survey: what's in it for us, and why should we care? ISME J 1: 185-187.

Okbamichael M, Sanudo-Wilhelmy SA. (2005). Direct determination of vitamin B1 in seawater by solid-phase extraction and high-performance liquid chromatography quantification. Limnol Oceanogr Methods 3: 241-246.

Okolodkov YB, Campos-Bautista G-L, Gonzalez-Gonzalez JAG, Hoppenrath M, Arenas V. (2007). Seasonal changes of benthic and epiphytic dinoflagellates in the Veracruz reef zone, Gulf of Mexico. Aquat Microb Ecol 47: 223-237.

Pan Y, Cembella AD, Quilliam MA. (1999). Cell cycle and toxin production in the benthic dinoflagellate Prorocentrum lima. Mar Biol 134: 541-549.

Panzeca C, Beck AJ, Leblanc K, Taylor GT, Hutchins DA, Sanudo-Wilhelmy SA. (2008). Potential cobalt limitation of vitamin B12 synthesis in the North Atlantic Ocean. Global Biogeochem Cycles 22: GB2029, doi:1029/2007GB003124.

Panzeca C, Tovar-Sanchez A, Agusti S, Reche I, Duarte CM, Taylor GT et al. (2006). B vitamins as regulators of phytoplankton dynamics. Eos 87: 593, 596.

Parsons ML, Preskitt LB. (2007). A survey of epiphytic dinoflagellates from the coastal waters of the island of Hawai'i. Harmful Algae 6: 658-669.

Pernthaler A, Pernthaler J, Amann R. (2002). Fluorescence in situ hybridization and catalyzed reporter deposition for the identification of marine bacteria. Appl Environ Microbiol 68: 3094-3101.

Petersen J, Brinkmann H, Pradella S. (2009). Diversity and evolution of repABC type plasmids in Rhodobacterales. Environ Microbiol 1462-2920.

Pischedda L, Poggiale JC, Cuny P, Gilbert F. (2008). Imaging oxygen distribution in marine sediments. The importance of bioturbation and sediment heterogeneity. Acta Biotheor 56: 123-135.

Pradella S, Allgaier M, Hoch C, Paeuker O, Stackebrandt E, Wagner-Dobler I. (2004). Genome organization and localization of the pufLM genes of the photosynthesis reaction center in phylogenetically diverse marine Alphaproteobacteria. Appl Environ Microbiol 70: 3360-3369.

Prokic I, Bruemmer F, Brigge T, Goertz H, Gerdts G, Schuett $\mathrm{C}$ et al. (1998). Bacteria of the Genus Roseobacter Associated with the Toxic Dinoflagellate Prorocentrum lima. Protist 149: 347-357.

Rabus R, Jack DL, Kelly DJ, Saier Jr MH. (1999). TRAP transporters: an ancient family of extracytoplasmic solute-receptor-dependent secondary active transporters. Microbiology 145: 3431-3445.

Rhodes CJ, Truscott JE, Martin AP. (2008). Viral infection as a regulator of oceanic phytoplankton populations. J Mar Syst 74: 216-226.

Rodionov DA, Vitreschak AG, Mironov AA, Gelfand MS. (2003). Comparative genomics of the vitamin B12 metabolism and regulation in prokaryotes. $\mathrm{J} \mathrm{Biol} \mathrm{Chem}$ 278: 41148-41159. 
Rossello-Mora R, Amann R. (2001). The species concept for prokaryotes. FEMS Microbiol Rev 25: 39-67.

Roth JR, Lawrence JG, Bobik TA. (1996). Cobalamin (coenzyme B12): synthesis and biological significance. Annu Rev Microbiol 50: 137-181.

Scott AI, Roessner CA. (2002). Biosynthesis of cobalamin (vitamin B(12)). Biochem Soc Trans 30: 613-620.

Sekar R, Pernthaler A, Pernthaler J, Warnecke F, Posch T, Amann R. (2003). An improved protocol for quantification of freshwater Actinobacteria by fluorescence in situ hybridization. Appl Environ Microbiol 69: 2928-2935.

Selje N, Simon M, Brinkhoff T. (2004). A newly discovered Roseobacter cluster in temperate and polar oceans. Nature 427: 445-448.

Seshadri R, Kravitz SA, Smarr L, Gilna P, Frazier M. (2007). CAMERA: a community resource for metagenomics. PloS Biol 5: e75.

Shiba T. (1991). Roseobacter litoralis gen. nov., sp. nov., and Roseobacter denitrificans sp. nov., aerobic pinkpigmented bacteria which contain bacteriochlorophyll a. Syst Appl Microbiol 14: 140-145.

Stackebrandt E, Frederiksen W, Garrity GM, Grimont PA, Kampfer P, Maiden MC et al. (2002). Report of the ad hoc committee for the re-evaluation of the species definition in bacteriology. Int. J Syst Evol Microbiol 52: 1043-1047.

Steunou AS, Jensen SI, Brecht E, Becraft ED, Bateson MM, Kilian $\mathrm{O}$ et al. (2008). Regulation of nif gene expression and the energetics of N2 fixation over the diel cycle in a hot spring microbial mat. ISME J 2: 364-378.

Swingley WD, Sadekar S, Mastrian SD, Matthies HJ, Hao J, Ramos H et al. (2007). The complete genome sequence of Roseobacter denitrificans reveals a mixotrophic rather than photosynthetic metabolism. J Bacteriol 189: $683-690$.

Tomaru Y, Nagasaki K. (2004). Widespread occurrence of viruses lytic to the bivalvekilling dinoflagellate Heterocapsa circularisquama along the western coast of Japan. Plankton Biol Ecol 51: 1-6.

Tyson GW, Banfield JF. (2008). Rapidly evolving CRISPRs implicated in acquired resistance of microorganisms to viruses. Environ Microbiol 10: 200-207.
Vander Horn PB, Backstrom AD, Stewart V, Begley TP. (1993). Structural genes for thiamine biosynthetic enzymes (thiCEFGH) in Escherichia coli K-12. J Bacteriol 175: 982-992.

Vershinin AO, Moruchkov AA, Leighfield T, Sukhanova IN, Pan'kov SL, Morton SL et al. (2005). Potentially toxic algae in the coastal phytoplankton of the northeast Black Sea in 2001-2002. Oceanology 45: 224-232.

Wagner-Dobler I, Biebl H. (2006). Environmental biology of the marine Roseobacter lineage. Annu Rev Microbiol 60: 255-280.

Wagner-Dobler I, Thiel V, Eberl L, Allgaier M, Bodor A, Meyer S et al. (2005). Discovery of complex mixtures of novel long-chain quorum sensing signals in freeliving and host-associated marine Alphaproteobacteria. Chembiochem 6: 2195-2206.

Wang JT, Douglas AE. (1997). Nutrients, signals, and photosynthate release by symbiotic algae: the impact of taurine on the dinoflagellate alga Symbiodinium from the sea anemone Aiptasia pulchella. Plant Physiol 114: 631-636.

Warren MJ, Raux E, Schubert HL, Escalante-Semerena JC. (2002). The biosynthesis of adenosylcobalamin (vitamin B12). Nat Prod Rep 19: 390-412.

Weinbauer MG. (2004). Ecology of prokaryotic viruses. FEMS Microbiol Rev 28: 127-181.

Williams HD, Zlosnik JE, Ryall B. (2007). Oxygen, cyanide and energy generation in the cystic fibrosis pathogen Pseudomonas aeruginosa. Adv Microb Physiol 52: 1-71-1-71.

Williamson SJ, Rusch DB, Yooseph S, Halpern AL, Heidelberg KB, Glass JI et al. (2008). The Sorcerer II Global Ocean Sampling Expedition: metagenomic characterization of viruses within aquatic microbial samples. PloS ONE 3: e1456.

Yoch DC. (2002). Dimethylsulfoniopropionate: its sources, role in the marine food web, and biological degradation to dimethylsulfide. Appl Environ Microbiol 68: 5804-5815.

Zielenkiewicz U, Ceglowski P. (2001). Mechanisms of plasmid stable maintenance with special focus on plasmid addiction systems. Acta Biochim Pol 48: 1003-1023.

Supplementary Information accompanies the paper on The ISME Journal website (http://www.nature.com/ismej) 